DEUIFD XLIV / 2016, ss. 211-243.

\title{
KISSA ÜSLUBÜ BAĞLAMINDA KUR'ÂN'DA EYYÛB PEYGAMBER
}

Yakup BIYIKOĞLU*

ÖZ

Kur'ân'ın kendine has bir kıssa üslubu vardır. Dolayısıyla Yüce Kitap, diğer kutsal kitaplardan ve diğer beşerî kitaplardan bu hususta üslûp olarak farkll11k arz eder. Nitekim Hz. Eyyûb kıssasına baktığımızda Kur'ân ayrıntıya girmeden kendine özgü bir üslupla toplam sekiz ayetle onun üzerinden veciz bir şekilde net mesajlar verir. Kitab-1 Mukaddes'e ve bu kültürden aktarllan rivâyetlere bakıldığında, Hz. Eyyûb ile ilgili ve özellikle malı, mülkü hastalığ1 öncesi ve sonrasıyla ilgili pek çok malzeme bulunabilir. Bu şekilde isrâiliyyât türü haberlerde anlatılan Eyyûb Peygamber, bir nebi şahsiyetini anlatmaktan uzak bir üslupta ve bir peygambere uygun olmayan tasvirlerle kıssa/hikâye edilmiştir. Oysaki bu haberlerin çoğu, onun Kur'ân'daki şahsiyetini gizlediği gibi, bunların çoğu gerçek de değildir. Velhasıl Yüce Allah, Kur'ân kıssa üslubu olarak Hz. Eyyûb üzerinden konuyu ayrıntıya dökmeden tüm insanlık ve inananlar için; "Allah'a sığınmak, tedavi olmak ve eşlere güzel davranmak" şeklinde üç öğüt/hatırlatmada bulunur. Özetle, Hz. Eyyûb kıssasında verilmek istenen mesaj; inanç ve ahlâka dair konularda sabırla Allah'a sığınmak; güzel bir kul örneği sunmaktır.

Anahtar Kelimeler: Uslûbü'l-Kur'ân, Hz. Eyyûb, İsrailiyyat, Kur'ân kıssalar1, Allah'a sığınma ve Sabır.

\section{PROPHET EYYUB IN THE CONTEXT OF PARABLE STYLE OF QURAN}

\section{ABSTRACT}

Quran has a distinctive parable style. In this respect it differs by other books and Bibles in terms of style. Considering the parable of Prophet Eyyub/Job, it is seen that Quran gives compendious messages briefly in eight verses by not entering into details but using its own style. When the Bible and the stories, which have been conveyed from that culture, are examined, it is seen that there is a great deal of information on Prophet Eyyub's property and the periods

* Yrd. Doç. Dr., Namık Kemal Üniversitesi, İlahiyat Fakültesi Tefsir Anabilim Dalı. e-mail: ybiyikoglu@,nku.edu.tr.

Makalenin Hakemlere Gönderiliş Tarihi : 18/11/2016

Makalenin Hakemlerden Geliş Tarihi : 10/12/2016 
before and after his illness. Prophet Eyyub, who has been narrated by israiliyyat sources, has been portrayed in a style that is not appropriate for the personality of a prophet and also he has been depicted with unsuitable descriptions. However most of this information is not true and they conceal his real personality which has been presented in Quran. Consequently, the almighty Allah, without giving details, exhorts three significant messages through Prophet Eyyub to whole humanity and believers: Taking "refuge in Allah, receiving treatment, being nice to wives and husbands". In short, the aimed message in the parable Prophet Eyyub is that taking refuge in Allah patiently in the context of belief and moral and presenting a nice model of creature.

Key words: Style of the Quran, Prophet Eyyub/Job, Israiliyyat, Parables of Quran, Refuge in Allah and Patience.

\section{Giriş}

Kur'ân-1 Kerîm'in konuların tasnif ve anlatımında kendine özgü bir üslubu vardır. Bu üslûbu anlamak için Kur'ân'1 ve ona ait ilimleri bilmek gerekir. Nitekim Kur'ân, diğer indirilen kitaplara nazaran muhatabını iyice tatmin etmek ve kendini kabul ettirmek için tedricilik esasına dayalı olarak ilahî bir üslup ortaya koyar. Bu husus, tefsirde Uslübu'l-Kur'ân diye ifadelendirilir. Uslûbu'l-Kur'ân içerik olarak Kur'ân'a has üsluba dair hususları konu edinir.

Konuların gönüllere hoş gelmesi, tefekküre davet etmesi, insanın madde ve ruhunu muhatap alması, sözlerin yerli yerinde kullanılıp anlaşılır olması, tekrarların usandırıcılık vermemesi, aile ve fert-toplumun ahlakî olarak güzelleştirmesi, dünyevî ve hukukî meselelerin çözümüne 1ş1k tutması, geçmiş asırdaki tarihî olayları en güzel üslup ile gözler önüne sermesi, mebde ve meâde dair gaybî hususları müşahhas kılarak ikna edici bir şekilde ortaya koyması, gaybî olan konuları hazır hale getiren meseller sunması ve her iki âlemin saadetini temin eden evrensel prensipleri sunması Kur'ân'ın aciz bırakan üslup şekillerinden bazısıdır'.

\footnotetext{
Kur'ân üslubundaki özellikler ve anlatımındaki incelikler konusunda bkz. Muhammed Abdulazim ez-Zürkanî, Menâhilü'l-İrfân fî Ulumi'l-Kur'ân, Dâru İhyâi'lKütübi'l-Arabiyye, ys. 1943, II, 205-226; İsmail Cerrahoğlu, Tefsir Usûlü, Türkiye Diyanet Vakfi Yay., Ankara 1985, s. 161-162.
} 
Araplar, bu hususları idrak ettiklerinde işlerine gelmese ya da yüz çevirmek isteseler de Kur'ân'ın üslubuna olan hayranlıklarını gizleyememişlerdir². Bu hususu İbn 'Aşûr (ö.1393/1973) şöyle anlatır: “Kim Kur'ân'ın i'caz yönüne Araplar gibi ulaşmak isterse, Arap lügati ve belagatinin ince ayrıntılarını, Arapların dillerindeki inceliğin verdiği haz düzeyinde veya buna yakın tarzda bilmesi gerekir. Zira Kur'ân'a bakıldığında, belagate dair hususlar olmadan Kur'ân'ın anlaşılmayacağı; ancak onun Arap belagati olarak i'caz yönlerini bilen âlimlerce doğru bir şekilde bilinebileceği aşikârdır”’3. Buradan hareketle Kur'ân'ın, muhatabını aciz bırakan yönlerini ve özellikle belagate dair üsluplarının anlaşılmasında Arap dilinin ve retoriğinin inceliklerinin bilinmesinin şart olduğu söylenebilir. Ayrıca şunu da belirtmek gerekir ki, Kur'ân iman, ahkâm, ahlâk ve kıssa anlatım üsluplarını ortaya koyarken tüm insanlığın idrak etmesi için beyan inceliklerini en anlaşıllır olarak gözler önüne sermektedir. Bu husus, Yüce Kitâb'in tüm insanlığa gönderilen beşer üzeri bir hitap olduğunu göstermektedir.

Yüce Kur'ân, önceki dönemlerde vaki olan kıssaları önceki kutsal kitaplardan farklı bir üslupla detaya inmeden canlı bir şekilde sunar. Oysaki diğer semavî kitaplarda genelde kıssa anlatım üslubu bunun aksinedir. Mukayese edilecek olursa Kur'ân, kendine has bir üslup ile önceki döneme ait olayları sürekli canlı tutarak anlatır. Kur'ân kıssalarının hedefinin ise maziye ait izleri ortaya çıkarmak ve bu şekilde insanların gaflet nedeniyle unutmuş oldukları tarihi olaylar-olgulara dikkatleri teksif etmek olduğu söylenebilirr. Böylece Kur'ân, hidayete davetin bir üslubu olan kıssalarla mevcut tarihi malzemeyi hak/gerçek ve veciz bir şekilde takdim eder. Nitekim Yüce kitap, "Bir, sana vabyetmek suretiyle kussalarn en

2 Kur'ân uslûbunun incelikleri konusunda etraflı bilgi için bkz. Ebû Bekir Muhammed Fevzî el-Behît, Hasâisu uslûbi'l-Kur'ânî, Melik Suûd Üniversitesi, Mekke 1436/2104, s. 30 vd.

3 Muhammed Tahir İbn 'Aşûr, et-Tahrîr ve't-Tenvîr, Müessesetü't-Târîh, Beyrût 2000, I, 344 .

4 İdris Şengül, “Kur'ân’ın Mesajını Ulaştırmada Kıssaların Önemi”, I. Kur'an Sempozyumu, IX, Ankara 1994, s. 134-135. Yine kissalar konusunda Kur'ân'daki kıssaların izdüşümü ve Allah merkezli bir dille anlatılmaları; kıssaların tarihle Örtüşmesi ve hak oluşlarının nasıllığı hususlarında bkz. Mustafa Öztürk, Kıssalarn Dili, Ankara Okulu Yay., Ankara 2010, s. 12-25. 
güzelini anlatyyoruz: Oysaki sen daha önceden bunlar bilmiyordun" ${ }^{5}$ beyanıyla, önceki peygamberler ve ümmetlerin kıssalarını en güzel bir üslup ile ortaya koyan bir kitap olduğunu haber verir.

Kur'ân kıssalarında nazım üslûbu olarak olguların sunulmasında benzerlikler ve faklıklar vardır. Kıssanın tek sûrede anlatılması söz konusu olduğu gibi, farklı sûrelerde dağınık parçalar halinde anlatıldığı da görülür. Kıssalarda benzerlikler olduğu gibi bunların çoğunda tekrarlarda görülür. Kısaların parçalar halinde sunulması Kur'ân'ın ilk muhatabı olduğu Arapların daha önce görmediği bir durumdu. Böyle olmakla beraber, Kur'ân'ın i'caz yönü üzerinde araştırma yapanlar, kıssaların tek bir sûrede değil de farklı sûrelerde olması hususuna eleştiri yapanlar da olmuştur. Bu eleştirilerin, Kur'ân kıssalarındaki hayrete bırakan edebî kullanımların idrak edilememesinden kaynaklandığı bir hakikattir. Zira Kur'ân, idrak eden ve görenler için üslup açısından diğer kitaplardan farklı şekilde gönderilmiştir ${ }^{6}$.

Kur'ân-1 Kerim'de k1ssa edilen peygamberlerden birisi Hz. Eyyûb'tür. Hakkında sekiz yerde bahsedilmekte olup onun, İsrailoğullarına gönderilen peygamberlerden olduğu belirtilir. Onun vahiy gönderilen bir peygamber olması şöyle haber verilir: "Ey Peygamber! T⿰亻⿻上丨 Nub'a ondan sonra gelen peygamberlere vahyettiğimiz, gibi sana da (bu Kur'ân'ı) vabyediyoru: İbrabim'e, İsmail'e, İshâk'a, Yakub'a ve evlatlarna, İsa'ya, Eyyûb'e, Yunus'a, Harun'a ve Süleyman'a da vabyetmis, Davud'a Zebur'u vermistik"'7. Onun kıssasında belirtilen vasıflarını Kur'ân'da Eyyûb başlı̆̆ında ayetlerle siralayacağız.

Allah (c.c), Kur'ân'da vahyin yanında, aldığ1 tebliğ görevini en iyi şekilde yerine getirmesi bağlamında sadece isim olarak Eyyûb Peygamberi İsrailoğullarına gönderilen peygamberler arasında zikreder ${ }^{8}$. Ayette görevini diğer peygamberler gibi onun da nübüvvet vazifesini en güzel

\footnotetext{
Yûsuf 12/3.

el-Behît, a.g.e., s. 240.

Nisâ 4/163.

8 'Bir İbrabim'e İshâk' ve (daha sonra torunu) Yakub'u bahșettik, bunlarn her birine, daba önce Nub'a vermiş olduğumuz, peygamberliği verdik. O'nun soyundan gelmis olan Davûd, Süleyman, Eyyûb, Yûsuf, Musa, Harûn'a da peygamberlik lütfettik. Biz görevlerini lâyzkıyla ve en güzel şekilde yerine getirenleri iște böyle ödüllendiririz’. En'am 6/84)
} 
şekilde ifa etmesi vasfina özellikle vurgu vardır. Zira kaynaklar da Hz. Eyyûb'den takva da önde, miskinlere karşı merhametli, yoksul ve yetimleri sahiplenen, misafirlere ikram eden, sürekli kavmini Allah'a kulluğa çağıran ve sabırlı bir nebî şeklinde bahseder?.

Biz, Eyyûb (a.s.) kıssasını üslup olarak ele alırken ve yine ayetleri yorumlarken özellikle rivâyet tefsirlerinden faydalanmayı önceleyeceğiz. Ancak ilk derli toplu tefsir olmas1 hasebiyle Taberînin (ö. 310/923) tefsirindeki rivayetleri dikkate almakla beraber, isrâiliyyât türü haberlere nispeten az yer vermesi ve hadisçiliği önceleyerek rivâyetler konusunda ihtiyatlı davranmas1 sebebiyle İbn Kesîr (ö.701/1301)'in Tefsirü'l-Kur'âni'lAz̨îm ve el-Bidâye ve'n-Nihâye adlı eserlerini merkeze alarak çalışmamızı şekillendireceğiz. Zira onun bu iki eseri, isnâd verilerindeki sağlamlılık ve isrâiliyyât türü haberler konusunda ihtiyat hususlarında diğer rivâyet içeren kaynaklara göre daha titiz olma vasfinı haizdir ${ }^{10}$.

Yine Taberî̀nin Tarib-i Taber̂̀ adlı eserinden, konuyla ilgili rivâyetleri barındıran dirâyet türü tefsirlerden, diğer İslâm tarihi alanındaki kaynaklardan ve bu rivayetlerin semavî dinlerdeki izdüşümünü mukayeseli olarak görmek için Kitab-1 Mukaddes'teki Hz. Eyyûb ile ilgili bilgilerden faydalanacağız.

Yöntem olarak ise meseleyi ayet ve tefsir bağlaminda merkeze almak suretiyle Yüce Kur'ân'ın, kıssa üslûbu olarak Hz. Eyyûb’ü nasıl anlattığını ve kıssayla hidayete davette onun üzerinden mesajlar verirken nasıl bir portre çizdiği ortaya koymaya çalışacağız.

\section{TARİHİ ŞAHSİYET OLARAK EYYÜB}

Kitab-1 Mukaddes'te ad1 İyyâb (iyôv) şeklinde geçmektedir ${ }^{11}$. Ancak bu kelimenin menşei ve anlamı tartışmalıdır. Düşman olmak, düşmanca davranmak anlamında âyav filinden geldiği söylendiği gibi, sabırla hastalığa katlanmak esnasında söylenen: "Ey ilahî baba nerdesin"

\footnotetext{
9 Afîf Abdulfettah Tabbâre, Ma'al-Enbiyâ fíl-Kur'âni'l-Kerîm, Mektebe-yi Mahmûdiye, İstanbul ts., s. 208.

10 Muhsin Demirci, Tefsir Tarihi, IFAV Yay., (4. Bask1), İstanbul 2008, s. 155.

11 Kitab-1 Mukaddes, Eski ve Yeni Abit, Kitab1 Mukaddes Şirketi, İstanbul, 1958, (Eyub, Bab: 1), s. 500.
} 
anlamına geldiği öne sürülmüş̧ür. Ancak Arapça olmayıp "tevbe etmek" anlamındaki evb köküne yakınlığı hususu da iddia edilmektedir ${ }^{12}$.

Tarih kaynaklarının bahsettiğine göre, Hz. Eyyûb, İshâk'nn (a.s.) oğlu 'İs'in torunlarındandır. Babası Mûs oğlu Râzıh'tır. Bilindiği üzere İshâk da İbrahim'in (a.s.) oğludur ${ }^{13}$. İbn Asâkir'e (571/1175) göre, Hz. Eyyûb'ün validesi Lût peygamberin kızıdır ${ }^{14}$. Dolayısıyla Eyyûb peygamberin nesebi hakkında değişik rivâyetler bulunmaktadır. Ayet-i kerimede “Onun (İbrabim'in) soyundan Dâvûd'a, Süleyman'a, Eyyûb'e, Yûsuf'a, Musa'ya ve Harûn'a..."15 olarak açıklandığ1 üzere Eyyûb peygamberin, Hz. İbrahim'in soyundan olduğu belirtilmektedir. Sahih olan görüşe göre ise ayette geçen “ "و من ذريته "ibaresinin sonundaki zamir, Hz. Nûh’a değil Hz. İbrahim'e râcidir ${ }^{16}$.

Hz. Eyyûb'ün Musul ve Ninova ahalisine peygamber olarak gönderilmiştir. Kur'ân'da çile ve hastalıklarla imtihan olmuş bu peygamber, Şam taraflarında pek çok evlât ve torunlara; geniş arazi ve mülk, sayısız mal ve servete sahip olmuştu. Emrinde bulunan insanların, kölelerin sayısı binlerin, davar ve hayvan sürülerinin sayısı on binlerin üzerindeydi ${ }^{17}$. Hz. Eyyûb, böyle nimetler içinde bol bir hayat yaşarken hastalıkla imtihan olmuş, Allah'ı sürekli zikreden kalbi ve dili dışında sağlam bir uzvu kalmamıştı. O, her durumda sabırlı ve hakkına razı bir kul idi. Bu halde gece- gündüz, sabah-akşam Allah'1 zikrediyordu. Hastalı̆̆1 artınca etrafindakiler ondan uzaklaşmaya başladı, yaşadığı beldeden çıkartıldı ve uygunsuz bir yerde eşiyle yaşamaya başladı. Eşi onun hukukunu, ahvalini gözetiyor, ona ihsanda bulunup şefkat

12 Ömer Faruk Harman, "Eyyûb”, DIA İstanbul 1995, XII, 16.

13 İbn Cerîr et-Taberî, Taribü't-Taberî, thk. Muhammed Ebu’l Fadl İbrahim, Beyrut ts., I, 322 .

14 Ali b. Hasan İbn Asâkir, Tehzibu Târihi Dimeşki'l-Kebîr, Dâru'l-Mesîre, Beyrut 1979, III, 194.

15 En'am 6/84.

16 Ebû'l-Fidâ İsmail İbn Kesîr, el-Bidâye ve'n-Nihâye, thk. Ebu'l-Muhsin et-Turkî, Dâru Hicr, Misir 1997, I, 506.

17 Komisyon, İslâm Tarihi, Osmanlı Yayınevi, İstanbul 1985, s. 149; Daha geniş bilgi için bkz. Ebû Muhammed b. Hüseyin b. Mes'ûd el-Begavî, Meâlimu't-Tenæî̀l, Dâru’lMarife, Beyrût, 1987, III, 256. 
gösteriyor; hastalığını iyileştirmek, hacetini gidermek ve bütün maslahatı için uğraşıyordu. Sonra hali zayıf düştü, malı azaldı ve eşi, Eyyûb’ü doyurmak ve onun tedavisi için insanlara hizmet karşıllı̆ı para kazanmaya başladı. Hanımı başına gelenden dolayı sabrediyordu. Mal ve çocuk ayrillğından sonra, eşine gelen hastalık musibet, saadet ve bolluk sonrasında düştüğü darlıkta, ona hizmet konusunda da sabirliydı. Eyyûb de eşi ve kendinin düştüğü bu durumlar için sürekli sabrediyor; Allah'a yönelerek hamd ve şükrediyordu. Bu nedenle "Eyyûb sabrr" tabiri onun için darb-1 mesel olmuştur ${ }^{18}$. Yine o, diğer ilahî dinlerde olduğu gibi İslâm dininde de sabır ve tahammül örneği olup eselerde daha çok bu vasfi ile anılmışı1' ${ }^{19}$. Eyyûb (a.s.)'ün şemaili ise kaynaklarda, uzun boylu büyük başlı, kıvırcık saçlı, güzel gözlü, kısa boyunlu, iri kol ve bacaklı olduğu şeklinde tavsif edilmektedir ${ }^{20}$.

Taberî̀ye göre Eyyûb Peygamber doksan üç yaşında vefat etmiştir. Vefat ederken oğlu Havmel'e hükümdarlık yapması için vasiyette bulunmuştur. Ondan sonra da idareyi oğlu Bişr almıştır. Ona tevhid konusunda dua etmiş; Bişr de 75 yaşında Şam'da vefat etmiştir ${ }^{21}$.

\section{HZ. EYYÛB'LE İLGİLİ RİVAYETLER}

İslâmî kaynaklarda, Hz. Eyyûb’ün şahsiyeti, hastalı̆̆ın süreci ve iyileşmesi, yemin etmesi, malının ve ehlinin kendisine döndürülmesi ilgili pek çok rivayet olup, imtihanın başladığı günden iyileştiği güne, daha sonra vefatına varıncaya kadar pek çok ayrıntılı malumat nakledilmiştir. İbn Kesîr ve hadis rivâyet kriterlerini öne alan âlimlerce belli bir tetkike tabi tutularak eserlerine nakledenlerin dişında; pek çok müfessir mervî haberleri araştırma ve incelemeye tâbi tutmadan tefsir külliyatına taşımıştır. Bunun nasıl ve ne maksatla taşındığı hususu ve bunları Kur'ân

18 Ebu'l-Fidâ İsmail İbn Kesîr, Tefsiru'l-Kurâni'l-Az̧îm, Dâru Taybe, Riyad 1997, V, 359; Tabbâre, a.g.e., s. 208-209.

19 Nurettin Albayrak, "Eyyub", Dذ், İstanbul 1995, XII, s. 17.

20 Ebû İshâk Ahmed es-Salebî, 'Ara ‘isu'l-Mecâlis/Kısasu'l-Enbiyâ, Matbaatü'l-Behiyye, Misır 1301/1883, s. 117. Onun şemaili, nesebi ve malları konusunda etraflı bilgi ve kaynaklar konusunda bkz. Asım Köksal, Peygamberler Taribi, TDV Yay., Ankara 1990, I, 305-306.

21 Taberî, Taribü't-Taberî, I, 324-25. 
tefsir aracı olarak kullanmaları ciddi bir problem olarak karşımızda durmaktadir.

\section{A- Kitab-1 Mukaddes'te Geçen Rivâyetler}

Kitab-1 Mukaddes'e gelince, burada Eyyûb peygamberle ilgili olarak bir bölüm ayırmıştır. Bu bölümde onun hakkında anlatılanlar Özetle şöyledir:

Uts diyarında yaşayan Eyyûb sâlih, kâmil Allah'tan korkan ve kötülüklerden çekinen; yedi oğlu, üç kızı olan ve ayrıca hayvanları bulunan çok zengin bir adamdı. Bir gün Allah, Şeytan'a: 'Dünyada Eyyûb gibi kâmil ve doğru birinin olmadığını, varlık sahibi olmasina rağmen Allah'tan korkup çekindiğini' söyledi. Şeytan da Allah'a: 'Olduğu şeylere dokunursan, onları elinden alırsan, hemen aleni şekilde sana lanet edecektir' dedi. Allah da şeytana firsat verdi. Eyyûb'ün canı dışında her şeye el uzatmasını söyledi.

Bundan sonra Şebalılar baskın yapıp Eyyûb’ün sığırlarını, merkeplerini götürdüler, hizmetçilerini öldürdüler. Keldanîler de develerini götürdüler ve uşaklarını öldürdüler. Gökten düşen ateş de koyunlarını yaktı. Oğulları ve kızları ağabeylerinin evinde yemek yerken firtına evi başlarına yıktı ve hepsi de enkazda öldüler. Tüm bu olanlar karşısında Eyyûb ise secde ederek: 'Anam bağrından çıplak çıtım ve oraya çıplak döneceğim. Rab verdi ve Rab aldı. Rabbin ismi mübarek olsun' dedi.

Bu kez Allah, Şeytana Eyyûb’ün nasıl sınavı başardığını söyleyip Eyyûb'ü övdü. Şeytan da Allah'a şayet canına dokunsaydın onun isyan edeceğini söyledi. Bu minvalde Rab, Şeytana: 'İşte o senin elinde, ancak onun canını esirge' dedi. Şeytan Eyyûb'ün ayağının tabanından tepesine kadar çıbanlar vurdu. Eyyûb kül içinde oturuyor, bir çömlek parçasıyla kazınıyordu. Onun bu yürek sızlatan haline acıyan üç dostu kalmıştı. Diğerleri ondan uzaklaşmışlardı. Karısı bu duruma dayanamayarak: 'Sen hâlâ kemâl durumunu sağlam mı tutuyorsun? Allah'a lanet ette öl' dedi. Fakat Eyyûb, Allah'a şükretti. Şeytan her ne kadar onun kalbini Allah'tan çevirmeye çalıştıysa da başaramadı. Eyyûb, sabır ile Allah'a yalvardı. Nihayet Allah Eyyûb'a ayağını yere vurmasını, oradan çıkan soğuk su ile 
yıkanmasını ve o sudan içmesini emretti. Eyyûb da suda yıkanıp sudan içince şifaya kavuştu. Sonunda kaybettiği malı ve evladı da bir kat fazlasıyla kendisine verildi. Rab, ona önceki malının iki katını verdi² ${ }^{2}$.

Kitab-1 Mukaddes'in ilk iki babında Eyyûb Peygamberin Allah'tan korkan doğru hulk-i kemâle ermiş bir insan olarak gösterilmesine rağmen, daha sonraki bölümlerde ise şeytanın onun hakkındaki tahminleri doğruymuş gibi şikayet ve isyankâr bir durum sergilenmesi enteresandır ${ }^{23}$. Dolayısıyla Eyyûb (a.s) ile ilgili söylenenlerin ne Allah'a ne de Eyyûb'e ait olmayacağını, bunların sonradan birisi tarafindan uydurulup Kitab-1 Mukaddes'e dâhil edildiği düşüncesi rahatlıkla söylenebilir ${ }^{24}$. Ayrıca Kitab-1 Mukaddes'te Eyyûb'ün hayatının sonunun başlangıcından daha bereketli olduğu, hayvanlarının daha da çoğaldığı, yedi oğlu, üç tane de kızının olduğu, kızlarının o diyarda en güzel olduğu ve sadece kızların isimleri zikredilerek babalarına varis oldukları belirtilir. Daha sonra yüz kırk yıl yaşadığı, dört göbekten torunlarını gördüğü, yaşlı bir şekilde ve günlerine doymuş olarak öldüğü zikredilir ${ }^{25}$.

Görüldüğü üzere Eski Ahitte Eyyûb (a.s.), toplamda k1rk iki babda geçmektedir. Tevrat'ın yaklaşık kırk sayfalık kısmı da Eyyûb’e ayrilmaktadır. Oysaki Hz. Eyyûb, Kur'ân'da sekiz ayette geçer ve Yüce Kitap onun hakkındaki kıssayı en beliğ üslûpla tevcîz eder. Hadislerde de bir iki rivâyetle onun duruma değinilmiştir. Hal böyle iken bunca isrâiliyyâta dayalı malzemenin Kur'ân tefsirlerine sirayet etmesi, sâbık kaynaklardan İslâm kültürüne ne türlü nakillerin olduğunu bariz bir şekilde ortaya koymaktadır.

\section{B- İslâm Kültüründeki Rivâyetler}

Hz. Peygamber'den rivâyet olarak Hz. Eyyûb’ün hastalığının başlangıç ve bitiş zamanını anlatan tek hadis vardır. Bu hadiste; onun çarşamba günü veya gecesi hastalığa (Cüzâm ve Abrasa) tutulduğu ve salı

22 Kitab1 Mukaddes, Eski Ahit, Eyub Bölümü, s. 500-501. Özet için bkz. Ateş, Süleyman, Yüce Kur'an'ın Cağdass Tefsiri, Yeni Ufuklar Neşriyat, İstanbul 1998, VII, 475-476.

23 Bir peygamberden sâdır olmayacak isyan ve beddua sözleri için bkz. Kitab-1 Mukaddes, Eski Ahit, Eyub Bölümü (Bab 3), s. 501-502.

24 Ebu'l A`la Mevdudî, Tefhimu'l-Kur'an. İnsan Yay. İstanbul 1986, III, 295.

25 Kitab-1 Mukaddes, Eski Ahit, Eyub Bölümü (Bab 42), s. 539. 
günü kurtulduğu belirtilir ${ }^{26}$. Enes b. Malik'ten nakledilen bir rivâyete göre, Eyyûb (a.s.) kendisine isabet eden bu hastalığ1 on sekiz y1l çekmiştir ${ }^{27}$. Yukarıdaki hadiste hastalığın nevi ile beraber hangi gün geldiği ve hastalıktan hangi gün kurtulduğu zikredilse de Hz. Eyyûb’e kaç yaşında iken isabet ettiği ve bundan ne zaman selamete erdiği belirtilmemiştir.

Ebû Hureyre'den gelen bir hadiste ise "Eyyûb (a.s.) çıplak olarak yıkandığı bir esna da üzerine altın çekirgeler dökülünce, bunları da avuç avuç alıp elbisesinin cebine koymaya başlamıştı. Bunun üzerine Rabbi ona: 'Şu gördüğgunden seni müstağni kılmamış miydım?' şeklinde nida edince Eyyûb: 'Evet senin izzetine yemin olsun ki bana çok şey verdin, fakat senin bereketinden müstağni kalamam demiştir." 28 .

Eyyûb (a.s.) ile ilgili Kur'ân'da belirtilen imtihanın sebeb-i vurûdu hakkında hadisin yanında, menkul pek çok rivayetler bulunmaktadır. Bunlara bakacak olursak, Taberî, Vehb b. Münebbih'ten (ö.110/728) naklettiği kıssada Hz. Eyyûb'ün malıyla ve evlatlarıyla, son olarak bedeniyle ilgili nasıl imtihanlara maruz kaldığını anlatır. Tüm bu sıkıntılara rağmen Hz. Eyyûb’ün, Rabbine karşı şikâyetçi olmadığını zikreder. Yine bir kısım insanların onun uğradığı felaketleri belli sebeplere atfetmeleri ve hakkında dedi-kodu yapmaları üzerine, Eyyûb nebinin Allah Teâla'dan belaları kendisinden kaldırmasını istediği ve

26 Bkz. Ebû Abdillah b. Muhammed İbn Mâce, Sünen, Çă̆r1 Yay., İstanbul 1992, Tibb, 22. Rivayetin isnâd zincirinde el-Hasan b. Ebi Ca'fer'in bulunması nedeniyle hadisin zayıf olduğu söylenir. Şöyle ki, el-Hâkim'in 'Müstedrek' adlı eserin de: Ziyad b. Yahya el-Hassânî o da Osman b. Muhammed b. Muhammed b. Cühâde tarikiyle gelen senetteki Osman hariç hepsi sikâdır. Çünkü adalet bakımından cerhi bilmediğini söyler. Yine isnadın İbn Ömer ile gelen bu hadisin sahih olduğu, ancak senetsiz ve kopuk olduğunu söyler. Yine Dârekutnî̀ye istinaden bu rivâyetin tek tarik ile geldiği söylenir. İbnu'l-Cevzî, el-'İlelu'l-Mutenâhiye'de Muhammed b. Cuhâde tarikiyle gelen bütün rivâyetlerin zayıf olduğunu söyler. Bkz. Şehâbeddin Ahmed b. Ebî Bekr el-Kinânü'l-Bûsîrî, Misbâbu'z-Zücâce fî̀ Zevâid-i İbn Mâce, Dârû'lCinân, Lübnan 1986, II, 215.

27 Sa’lebî, 'Ara 'isü'l-Mecâlis, s. 122; İbn Kesir, Bidâye, I, s. 510.

28 Ahmed b. Hanbel, el-Müsned, Çağr1 Yay., İstanbul 1992, 243, 314, 490; Muhammed İsmail el-Buharî, Câmiu's-Sahîh, Çağri Yay., İstanbul 1992, “Gusül”, 20, Enbiyâ, 20, "Tevhîd, 35. 
bunun üzerine O'nun da imtihanın üzerinden kaldırdığını zikreder. Bu konunun devaminı da tefsirinde uzun uzadiya anlatır ${ }^{29}$.

Taberî'de geçen rivayetleri, tarihe dair eserindeki malumatla müşterek verecek olursak, Vehb b. Münebbih'ten rivayetle; meleklerin duası dişındaki hususlara İblis ulaşamadı. Bu hususta kendisine bir mani konuldu. Ancak İblis meleklerin Eyyûb hakkındaki duasını işittiğinde, kendinde azgınlık ve haset oluştu. Hızlıca Allah'ın indine çıkarak şöyle seslendi: Tanrım! Senin kulun Eyyûb'ün haline baktım. Onu senin verdiğin nimetlerde şükreden buldum. Hamd konusunda onu afiyette gördüm. Ancak onu şiddetli bir zorluk ve belâ ile onu sınamadın. Ben iddia ediyorum ki, belâ ile onu zor durumda bırakırsan seni inkâr edecek, seni unutacak ve senden başkasına tapacak. Allah da ona: 'Git malına musallat ol. Göreceksin her durumda bana şükredecek. Lakin sen onun cesedine ve aklına musallat olamayacaksin ${ }^{30}$. Taberî, tefsirinde uzunca yer verdiği bu rivâyeti, tarihe dair eserinde ihtisar ederek şöyle anlatır:

"Allah İblis'i onun aklı ve cesedi hariç malına musallat kıldı. Böylece İblis, şeytanlardan ifritleri ve önde gelenleri topladı. Eyyûb de bu esnada Şam'in doğusu ile batısı arasında Seniyye adlı bir yerde idi. Bin sürüsü, beş yüz kölenin tabi olduğu beş yüz cariyesi vardı. Her bir kölesinin eşi çocuğu ve malı vardı (...) İblis avenelerini topladığında onlara: 'Yanınızda kuvvet ve marifet olarak ne var dedi? Ben ise Eyyûb'ün malına musallat oldum. Bu, erkeklerin sabredemeyecekleri korkunç bir musibet ve fitnedir' dedi" "31. Başat Müfessir Zemahşerî (ö. $538 / 1143)^{32}$ ve günümüz müfessiri Elmalılı'nın ${ }^{33}$, baz1 dirâyet

29 Ebû Cerîr et-Taberî, Câmiu'l-Beyân an Te'vîli'l-Âyi'l-Kur'ân, thk., Abdu'l-Muhsin etTürkî, Dâru Hicr, Kahire 2001, XVI, 334. Taberî, bu husus da ne kadar malumat varsa, hatta kurdun bedeninden düşmesi hususuna varıncaya değin toplayıp eserine derç etmiştir. Bunların çoğunu, kıssanın anlaşılmasına katkı sağlamayacağından ve peygambere isnâd edilmesinin itikadî bağlamda sorun teşkil edeceğinden çalışmamıza katmayacağız. Bkz. Taberî, Câmin'l-Beyân, XVI, 335 vd.

30 Taberî, Câmiu'l-Beyân, XVI, 334.

31 Taberî, Taribi, I, 323.

32 Zemaşerî nesebi, eli ve mal varlığı hakkında kısa net bilgi verip, Eyyûb’ün hastalık süresi ilgili muhtelif haberler dışında isrâiliyyât türü malzemelere yer vermez. Bkz. Mamûd b. Ömer ez-Zemahşerî, Keşşâf, Dâru İhyâi't-Türasi'l-Arabiyye, Beyrut 1997, III, 131. 
tefsirlerinde geçmesine rağmen, Enbiya sûresi 83-84. ayetlerin tefsir ederken bu rivâyetlere hiç değinmemeleri, bunların isrâiliyyâta dair dolgu malzemesinden öteye gitmediğini açıkça ortaya koymaktadır.

Biz burada Hz. Eyyûb ile ilgili tefsir kültürüne taşınan rivâyetlerin hepsini, çalışmamızın kapsamına dâhil etmeyeceğiz. Zira bu hususta yüklü bir malzeme yığınıyla karşılaşmaktayız. Özetleyecek olursak, hastalığına kadar Eyyûb'ün (a.s.) şahsiyeti, İblis'in Hz. Eyyûb’ün malı ve vücuduna musallat olması, hastalığının çeşidi, kurtların vücudunu sarması ve mezbele bir yere atılmas1, Allah'tan afiyet istemesi, iyileştikten sonra hanıma yüz sopa atacağına dair yemin etmesi ve son olarak da mal ve mülkünün geri verilmesi şeklindeki haberler ${ }^{34}$ nazar-1 dikkate alındığında, İslamî kaynaklardaki isrâiliyyâta dair rivâyet hacminin nerelere vardığı açıkça görülür.

\section{C- İsrâiliyyât Türü Rivâyetlerin Değerlendirilmesi}

Burada öncelikli olarak Kur'ân'’n açıklanmasında derç edilen rivâyetlerin tefsirî değeri üzerinde mütalaada bulunacağız. Zira Kitab-1 Mukaddes'teki Hz. Eyyûb'a dair haberlerin farklı varyantlar halinde tefsir ve hadis kültürümüze sirayet ettiği malumdur.

Öncelikle belirtmek gerekir ki, Kur'ân tefsiri hususunda elde mevcut ve mahfuz İslamî olan rivâyetlerle yetinilmediği için, Tevrat, İncil ve bunlara müteallik yazılan şerhlere müracaat edilmiş; bu tür rivâyetler, gerek şifahî, gerekse yaz1lı olarak Ehl-i Kitâb bilgisi olarak "isrâiliyyât"” ismiyle tefsir sahasına yığılır hale gelmiştir. Nitekim aslı olmayan bu tür hurafeler, İslâm’a ait nice eşsiz güzellikleri gölgelemiştir ${ }^{36}$.

33 Elmalılı Ahmed Hamdi Yazır, Hak Dini Kur'an Dili, Eser Dağıtım, ys. 1979, V, 3365.

34 Hz. Eyyûb ile ilgili özellikle tefsir kaynaklarında geçen rivâyetlerin tamamı için bkz. Aydemir, Abdullah, İslâmî Kaynaklara Göre Peygamberler, TDV Yay., Ankara 1992, s. 97-112.

35 İsrâiliyyâtın tanımı, nevileri, bu tür haberlere riayet edip etmemeyi gerektiren durumlar ve bunların naklini yasaklayan veya tecviz kılan hadisler konusunda bkz. Abdullah Aydemir, Tefsirde Israiliyyat, Beyan Yayınları, İstanbul 1992, s. 29-63.

36 Aydemir, a.g.e., s. 28. Bu husustaki asılsız pek çok malzeme, dini anlatma ve ihtida vs amaçlarla anlatılmış ve bunlar, din adına bunlar müstakil eserlerde toplanarak derç edilmiştir. Genel de rivâyetlerde Ka‘bu’l-Ahbar ve Vehb b Münebbih’ten 
Kelâmî/itikâdî bağlamda Eyyûb (a.s.) ile ilgili bu tür rivâyetlerin itikâdî olarak olumsuz sonuçlar doğuracağ1 zikredilmektedir. Şöyle ki, kelâmcılar, peygamberlerin sıfatlarına altıncı sıfat olarak "vücut sağlığı"nı da eklemişlerdir. Bundan maksat, peygamberlere hastalığın isabet etmeyeceği değil, nefret edilen kusurlardan salim olmalarıdır ${ }^{37}$. Bu hususta Eş’arî kelâmcı Teftazânî (ö.793/1390), peygamberlerin sürekli insanlar arasında bulunması gerektiğinden, insanları tiksindirecek bir durumun onlardan sadır olmayacağını söyler. Zira onlara uymak ve davetlerini dinlemek hususlarında, peygamberlerin nefret ikrah oluşturacak bedenî ve ahlakî kusurlardan uzak olmaları gerekir. Nebilerin, kaba, kötü kalplı, sert yürekli, kibirli, ikiyüzlü, münafik korkak, hasetçi, öfkeli vs olmaları ve yine Cüzzam ve Abras gibi tiksinti oluşturacak hastalıklara yakalanmaları mümkün görülmez ${ }^{38}$. Zira bu tür hususlar insanların kaçmalarına ve uzaklaşmalarına sebep olur. Oysaki insanların nebilere yakın olmaları, 1sınmalar1 ve onları sevmeleri gerekir ${ }^{39}$. Kitab-1 Mukaddes'teki isrâiliyyât malzemelerinden İslâmî kaynaklara nakledilen Hz. Eyyûb'e ait hususlar, ne Kur'ân ne de sünnetteki peygamber tasviriyle asla örtüşmez. Ancak Ahd-i Atik'e bakıldığında birakın peygamberlere, Tanriya dahi bir takım beşeri zafiyet ve eksiklikler rahatlıkla izafe edilebilmiştir. Oysaki bir peygamberin ismet sıfatına uygun düşmeyen bu tür tasvirler ${ }^{40}$, Kur'ân-1 Kerim'in anlattı̆̆1 Eyyûb'e (a.s.) ait üsluba tamamen zittır.

Ayette Hz. Eyyûb: "Şeytan beni yorgunluğa (meşakekat) ve azaba (hastahk) uğrattı" ${ }^{41}$ der. Oysaki Ehl-i Kitâb kaynaklara ve bazı iddialar

nakledilmiştir. Bkz. Ahmed Bican Yazıcıoğlu, Envâru'l Âşıkîn, Sağlam Kitabevi, İstanbul 1974, s. 119-124.

37 Mehmet Bulut, Ehli Sünnet ve Şia'da İsmet İnancr, Risale Yay., İstanbul 1991, s. 20.

38 Ömer b. Abdillah Sa'duddin Teftazânî, Şerbu'l-Makâsıd, İstanbul 1277/1860, II, 146; ayrica bkz. Abdu'l-Vehhâb en-Neccâr, Kısasu'l-Enbiyâ, Mektebe-i Dâri't-Türâs, Kahire ts., s. 416.

39 Bulut, a.g.e., s. 20-21.

40 Kitâb-1 Mukaddes'te bir peygamberden sâdır olmayacak durum tasvirlerin Hz. Eyyûb'e isnat edildiği rahatlıkla görülür. Şöyle ki, beddua edip lanet okunası (Bab, 3), istırap-usanmak (Bab, 3), ümitsizlik sabırsızlık ve acziyet (Bab, 6), yaşama isyan ve sitem dolu sözler (Bab, 7, 21), hastalıktan şikâyet (Bab, 20) ve günahkârlık (Bab, 34). Bkz. Kitab-1 Mukaddes, Eski Ahit, s. 501-531.

41 Sâd 38/41. 
göre, bu azabın bir ceza olduğu ve dolayısıyla onun günahkâr olduğu söylenir. Fahreddin Râzî (ö. 606/1209) bu iddiaları şöyle cevaplandırır: Her azap ceza değildir. Mesela, zulme uğrayan bir insana ceza verildi denmez. Burada Hz. Eyyûb, hastalığ Şeytan'a izafe etmemiş, sadece vesvesesi sebebiyle düştüğü sıkıntıdan bahsetmiştir. Hz. Eyyûb hastalanınca bunu firsat gören Şeytan, onun halkına ondan uzaklaşmaları için vesveseyle telkinde bulunmuştur. Ayette ise günahkâr olması ve azaba uğramasının aksine; "Biæ, onu hakikaten saburl bulduk. O ne güzel bir kuldu. Hakikaten daima Allab'a yönelen biriydi" ${ }^{42}$ şeklinde övülmüştür ${ }^{43}$. Eğer ayetteki nusb ve azâb ifadeleri ${ }^{44}$, onun günahkâr olduğuna delalet olsa, iki ayet sonra Allah Teâla onu niçin övmüştür? Burada Hz. Eyyûb'ün meşakkat ve azabı Şeytân'a isnat etmesi, onun Allah'a karşı edebindeki olgunluğundandır ${ }^{45}$.

Sonuç olarak, Ehl-i Kitâb’a dair bu tür rivâyetleri iyi bir tetkike tabi tutmadan tefsirlere taşıyan nakilciler büyük vebal almışlardır. Sözde Eyyûb’ü (a.s.) sabırlı göstererek halkın gözünde büyütmek iddiasında olanlar, yarasından düssecek kurtları alıp geri koyacak kadar sabırlı ve kurdun bile hukukunu düşünen şeklinde onu tasvir etmek suretiyle nice insanları da dinden soğutmuşlardır. Maalesef bu anlatılanları hurafe ve asılsız olduğunu bilmeyenler Allah'ın kelâmını açıklayıcı olarak bunları yayıp durmuşlardır ${ }^{46}$. Yapılacak en önemli şey, kelâmullaha ve sünnete uymayan ve bunlarca tasdik edilmeyen isrâiliyyât haberleri titizlikle ayıklayarak tefsir kitaplarından çıkarmaktır. Böylece Kur'ân-1 Kerim'in beyan ettiği peygamber ahvallerini örten küller dağılacak, kıssalarla ilgili ana mesaj ortaya çıkacaktır.

42 Sâd 38/44.

43 Fahreddin Râzî, 'İsmetü'l-Enbiyâ, Mektebetü's-Sekâfetü’d-Diniyye, Kahire 1986, s. 97; ayrıca bütün peygamberlerin ismet sıfatına sahip olmas1 ve günahlardan masum olduklarına dair görüşler için bkz. Yakup Yüksel, Allah’n Uyard̆̌̆g Peygamberler, Rağbet Yay., İstanbul 2016, s. 42-49.

44 Sâd 38/41.

45 Peygamberlere isnat edilen günahlar ile ilgili bkz. Durmuş Özbek, Sadududdin Teftazanî ve Nübürvet Görüşü, Sebat Ofset, Konya 2002, s. 163.

46 Aydemir, İslâmî Kaynaklara Göre Peygamberler, s. 111. 


\section{KUR'ÂN-I KERİM'DE HZ. EYYÛB}

Eyyûb'ün (a.s.) ismi Kur'ân'da dört ayrı sûrede olmak üzere, toplam sekiz yerde doğrudan; Nisâ ve En'âm sûrelerinde ise sadece nebi ismi şeklinde geçmektedir. Enbiyâ ve Sâd sûrelerinde ise yaşamından konulu olarak haber verilerek Hz. Eyyûb kıssa edilmektedir.

Yüce Allah peş peşe üç ayette ${ }^{47}$ tam on üç peygamberden bahseder ve onları kronolojik olarak tarih sırasına göre siralar. Kur'ân, indiriliş nedenini, bir tarih kaynağ1 vasfinda değil, hidayet ve ögüt kitabı olarak anlatmaktadır. Yine peygamberler, üstünlük ve menkıbelerine göre de Kur'ân'da sıralanmamıştır. Zira Kur'ân, menkıbe ve övgü kitabı değil, öğü ve ibret kitabıdır. Yüce Allah, mezkûr ayetlerdeki peygamber isimlerini aralarındaki benzerlikten dolayı üç kısımda zikreder.

En'âm 84. ayetteki altı peygamberin ortak özelliği, kendilerine nübüvvet ve risâlet yanında, mülk, imâret ve hüküm verme bahşedilmiş olmasıdır. Baba oğul olan Hz. Dâvûd ve Süleyman zikredildikten sonra Hz. Eyyûb ve Hz. Yûsuftan bahsedilmiştir. Eyyûb (a.s.) de ihsan sahibi, büyük ve zengin bir emir idi. Yûsuf (a.s.) ise dilediğini yapabilen hâkim ve büyük bir vezir idi. Fakat bunların ikisi de -refah ve bollukta imtihanla şükrettikleri gibi- sıkıntılarla imtihan edildiler. Benzer şekilde sabretmişlerdir ${ }^{48}$.

İmtihanı hakkında Hz. Eyyûb ile ilgili Kur’ân şöyle der: "Hani Eyyûb Rabbine: Rabbim başıma bir dert geldi (bu dert beni sarverdi). Sen merbamet edenlerin en yücesisin' niyaz etmiști. Biz de onun duasm kabul etmis,s, onu

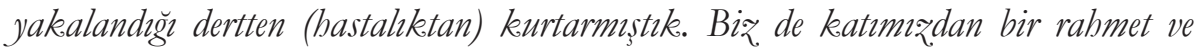
kulluk edenlere bir hattra olmak üzere ona hem ailesini, hem de kaybettiklerini misliyle verdik" "49 Tefsirlere göre İbn Ebî Hatim'den (ö. 327/939) nakille Eyyûb (a.s.) şöyle dermiş: Rabbim bana mal ve çocuk verdin, yanlışımdan dolayı şimdiye değin şikâyet için kimse kapıma dikilmedi. Bunu sen biliyorsun. Yine kendim için yatak hazırlandığında, yatağı terk eder;

\footnotetext{
En'âm 6/84-86.

48 Muhammed Reşid Rıza, Tefsirü'l-Menâr, Dâru'l-Marife, Beyrût ts., VII, 587.

49 Enbiyâ 21/83-84.
} 
nefsime; 'ey nefis şüphesiz ben yatakta yatmak için yaratılmadım' derdim ${ }^{50}$.

Hz. Eyyûb'ün hastalığına dair bu rivâyeti, Vehb b. Münebbih ${ }^{51}$ uzun uzadıya anlatır. İbn Cerîr ve İbn Ebî Hatim ve daha sonraki müfessirler de bu geleneği devam ettirilmişlerdir. Ancak İbn Kesîr, uzun ve gereksiz tavsif ettiği bu kıssayı terk eder ve rivâyetinin garip olduğunu söyler ${ }^{52}$.

Hz. Eyyûb (a.s)'ün “...bana dert geldi...” beyanıyla musibetin mahiyetinin Şeytan'in musallat olmasından kaynaklanan hastalık olduğunu başka bir ayetten anliyoruz. Zira ayet şöyledir: "Ey Peygamber! Kulumuг, Eyyûb'ü da hatorla (sende onun gibi sabrrl ol). Hani Rabbine söyle demisti: Rabbim bana Seytan musallat oldu, onulmaz bir hastalğga yakalandim, balsiz-mecalsiz, kaldom" "53. Taberî, bunun (derdin) Allah'ın verdiği belâya duçar ve bu konuda imtihana maruz kalmak olduğunu söyler ${ }^{54}$. Bu hastalığın kadar sürdügü konusunda ihtilaflar vardır ${ }^{55}$. Şöyle hastalığın üç sene, yedi sene birkaç ay ve on sekiz sene sürdüğüne dair rivâyetler $\operatorname{vardir}^{56}$. Hasan el-Basrî, ve Katade, Eyyûb'ün (a.s.) yedi sene birkaç ay İsrailoğulları mezbeleliğine atılarak musibete duçar kaldığını söylemişlerdir ${ }^{57}$. Orada bedeni üzerine haşarat dolaşırmış. Sonra Allah Teâla ondan bu musibeti kaldırarak ecrini çoğaltmış ve onun için güzel

50 Muhamed b. İdris, İbn Ebî Hâtim, Tefsiru'l-Kur'âni'l-Azı̂m, thk. Es'ad Muhammed Tayyib, Mektebetu Nizâr, Riyad 1997, VIII, 2459; İbn Kesîr, Tefsiri, V, 359-360.

51 Vehb. b. Münebbih için hakkında kezzâb vasfinın denmesi ağır bir durum olsa da İsrâilî rivâyetlerin büyük bir kısmının, onun vasıtasıyla İslâm'a, özellikle de tefsir kültürüne girdiği rahatlıkla söylenebilir. Bkz. Aydemir, Tefsirde İsrailiyyat, s. 100.

52 İbn Kesîr, Tefsiri, V, 360.

53 Sâd 38/41.

54 Taberî, Câmin'l-Beyân, XVI, 333.

55 Mücâhid'e göre, Hz. Eyyûb’ün yakalandığı illet, çiçek hastalığıdır. Bkz. İbn Kesir, Bidâye, I, 508; ancak bunun uyuz ve cüzzam olduğu söylense de bu rivâyetlerin hiçbirine itibar edilmez ve doğru da değillerdir. Burada asıl olan sabırla Allah'a sığınamak suretiyle şifa aramaktır. Bkz. Merağ̂̀, Ahmed Mustafa, Tefsiri Merağı Misır 1974, XXIII, 124-25.

56 Tabbâre, a.g.e., s. 209.

57 İbn Kesîr, Tefsiri, V, 360. 
bir övgüde bulunmuştur. Süddi ise Eyyûb'ün bu durumu şöyle anlatır: Etlerinin dökülmeye başladı, sinir ve kemiklerinin dışında başka bir şey kalmadı. Böylece karısı onun bütün işlerini görüyor ve bulunduğu yere azığını getiriyordu. Ağrı sızısı artınca karısı ona: 'Ey Eyyûb, Rabbine dua et de senden bu belayı gidersin derdi'. Eyyûb da: 'yetmiş sene sağlıklı olarak yaşadım. Allah için yedi sene yaşamam çok mudur?’ şeklinde cevap vermişti ${ }^{58}$.

Hz. Eyyûb'ün hastalığı ve sonrası hakkındaki rivâyetlerde; yaralarının kurtlanması ve adeta fokur fokur kaynaması, bu halde iken Eyyûb (a.s.), yaralarından düşen kurtları geri koyarak; 'ye bunlardan senin nasibin var!' demesi ${ }^{59}$, onun yaralarından kurtların dökülmesi sonrasında ortalığı bir koku sarınca şehir halkının kendisini şehirden uzaklaştırıp bir mezbeleliğe bırakması ve yanında eşinden başka kimse kalmayıp yılarca burada kalması uzun uzadiya anlatılmaktadır ${ }^{60}$. Oysaki Allah'ın masum elçileri maddi ve manevi bakımdan temiz insanlardır. Vazifeleri gereği toplumun içinde yaşarlar. Hiçbir peygamber insanları nefrete düşürecek, şehirden sürülüp uzağa atılacak düzeyde hasta olamaz. Bu tür haberler,

58 Bkz. İbn Kesîr Bidaye, I, 509; Bu konuda İbn Kesîr'de farklı görüşler vardır. Şöyle ki, Eyyûb'ün karısı, ücret karşılığı insanlara iş görüyordu. Kazandıklarını da Eyyûb'a getirip onu doyuruyordu. Rivâyete göre İblis, Hz. Eyyûb’un Filistin'den dostu olan iki kişiye gitti. Onlara: 'Kardeşiniz Eyyûb’a şöyle bir belâ isabet etti. Ona gidin, onu ziyaret edin ve bir miktar ülkenizin içkisinden yanınıza alın. Eğer bundan içerse iyileșir' dedi. Eyyûb'ün iki arkadaşı da ona geldiler. Arkadaşları ona baktıklarında ağladılar. Hz. Eyyûb onlara; 'siz kimsiniz?’ dedi. Onlar da filan falanız dediler. Bunun üzerine onlara merhaba dedi ve: 'Beni musibet anında terk etmeyene" merhaba diye ekledi. Onlar: 'Ey Eyyûb, belki sen bir şey gizledin ve gizlediğinin dışında gizlediğin bir şeyi izhar etin de, bundan dolayı Allah seni bu musibete duçar kıldı dediler. Hz. Eyyûb başını göğe kaldırdı ve şöyle dedi: O biliyor ki ben bir şeyi saklayıp onun dışında bir şeyi izhar edemedim. Lakin Rabbim, ben sabredecek miyim, yoksa feryat $m$ edeceğim buna bakmak için beni bu bela (imtihan)'a tâbi kıldı. Onlar kendisine; 'Eyyûb bizim içkimizden iç. Eğer içersen iyileşeceksin' dediler. Oda: 'Bunu size habis Şeytan mı emretti?' Dedi. Kızarak sözünüz, yiyeceğiniz ve içeceğiniz haram üzeredir dedi. Bunun üzerine yanından kalkıp gittiler. Bunlar için bkz. İbn Kesîr, Tefsiri, V, 360-361.

59 Taberî, Tefsiri, XVI, 353, 359. Muhammed b. Abdilkerim İbnu'l-Esir, el-Kâmil fi'tTârih, Dâru Beyrût, Beyrût, ts., I, 129; Şihâbudin Seyyid Mahmûd el-Alûsî, Rubu'lMeânî, İhyau Türâsi'l-Arabî, Beyrut ts., XVII, 80.

60 Taberî, Câmiu'l-Beyân, XVI, 339; Fahreddin er-Râzi, Mefâtibu'l-Gayb, Dâru'l-Fikr, Beyrût 1981, XXII, 205; el-Kâmil fi't-Târih, I, 129. 
caiz olmayıp yalan olan isrâiliyyât türündendir. Bunları doğrulayacak elimizde hiçbir sağlam senet de yoktur ${ }^{61}$. İçerik olarak da bakıldığında, nefret uyandıracak bu tür hastalıklar ve peygamberlik taban tabana zıttır.

Yine şöyle rivâyet edilir: Hastalık kendilerine bulaşır endişesiyle Hz. Eyyûb'ün karısına, hizmetçilik yaptırmıor ve onu aralarına katmıyorlardı. Hanımı da parasızlık endişesinden dolayı kendi saç örgülerinden birini keserek, bir şeyler satın almak için eşraftan birinin kızına sattı. Aldığı şeyleri Hz. Eyyûb'e götürdü. $\mathrm{O}$ da; 'bunları nereden buldun?' şeklinde sorunca karısı da; 'hizmetçilik yaparak kazandığını' dedi. Ertesi gün, yine kendisine iş verecek kimse bulamadı. Bu kez saçının diğer örgüsünü sattı. Hz. Eyyûb, bunları nereden bulduğunu tekrar sordu. Bu sefer hanımı söylemeyince o da yiyecekleri nereden bulup getirdiğini söylemedikçe hiçbir şey yemeyeceğine dair yemin etti. Bunun üzerine karısı başını açtı. Saçlarının kesilmiş olduğunu görünce, Mevla'ya şöyle bir yakarışta bulundu: 'Rabbim! Bu dert bana dokundu. Sen merhametlilerin en merhametlisisin ${ }^{92}$.

Ayetlerin tefsirine gelince, Maturîdî (ö. 333/944) "Eyyûb, dert eza geldi ded"" ve "Şeytan bana dert azap verd" ayetlerinin anlam olarak birbirini tamamladığını söyler. O, isrâiliyyât türü haberlere girmeden ayet etrafinda özet yorum yapar. Şöyle ki Allah, Süleyman (a.s.)'1 şeytanlar üzerine musallat kıldı ve onun emrine verdi. Bu kıssada ise $\mathrm{Hz}$. Süleyman'ın aksi olarak bu sefer Şeytanı Hz. Eyyûb'e musallat kıldı. Nitekim ayette bu husus, “...mubakkak ki Şeytan bana yorgunluk ve azap verdi/أنى مسنى الشيطان بنصب و عذاب....” (Sâd 38/41) şeklinde belirtilmiştir. Geçmişte Allah'a karşı yüz çevirme durumu olmadığı gibi, kendine müstahak görülen durumdan ötürü de isyan etmemişti. Aslında Allah, ona selamet, rahmet ve nimet veriyordu. Dilediğine dilediğini vermesi; dilediğini mahrum bırakması Onun şanının özelliğidir. Ayetin sonunda da belirtildiği gibi, durumu aksine çevirerek belayı ondan kaldırılması,

\footnotetext{
61 Alûsî, Rûhu'l-Meâni, XXIII, 208; Merağ̂̀, Tefsirî, XVII, 61; Mehmed Vehbî Efendi, Hülâsatü'l-Beyân, Ahmet Sait Matbaası, İstanbul 1968, I, 3469.

62 İbn Kesîr, Bidâye, I, 509.

63 Enbiyâ 21/83.

64 Sâd 38/41.
} 
kendisine verilen bir rahmet idi. Ĕger farklı bir durum olsayd1, ayette rahmet zikredilmezdi. Bu husus aynı zamanda Mu'tezile mezhebine cevap mahiyeti taşır ${ }^{65}$. Şöyle ki onlara göre aslah (uygun) olanı yaratmak Allah üzerine vaciptir. Ancak ayette Hz. Eyyûb'e isabet eden bela Şeytan’a izafe edilmiştir. Bu durum ise “مسنى الشيطان” şeklinde ayette belirtilmiştir. Onlara göre bu musibet aslah olan bir durum olsaydı, Allah bunu Şeytan'a izafe etmezdi. Zira bu husus, onların vardıkları görüşe delil olmaz. Ayette Hz. Eyyûb, zimnî dua olarak merhamet ve afiyet istemektedir. Sonraki ayette de halden kurtulduğu belirtilmektedir. Böylece Allah (c.c.), duanın çıkış yolu olduğunu kıssada göstermiştir ${ }^{66}$. Aynı şekilde ayette, fiili dua bağlamında bu hastalığın tedavisinin nasıl olacağ1 da "Ayağmn yere vur. İste ynkamlacak ve içilecek soğuk su bu" "67 ayetiyle kendisine anlatılmıştır. Bu konuyu bir sonraki bölümde "tedavi olmak" başlı̆̆ı altında etraflıca ele alacağız.

Hz. Eyyûb'ün hastalık ve sıkıntılarla imtihandan sonra duasının kabul edilmesi, başına gelen zararın giderilmesi ve malının mülkünün kendine iadesi şöyle anlatılır: "Biz, de katımı̨dan bir rahmet ve kulluk edenlere bir hatura olmak üzere ona hem ailesini, hem de kaybettiklerini misliyle verdik" ${ }^{68}$ ve "Katımızdan bir lütuf olmak üzere Eyyûb'e ailesini, mal ve evlatlarm misliyle verdik ve bu akel sahipleri için bir ögüttür " ${ }^{\prime 69}$. Ayetlerden anlaşıldığ1 üzere $\mathrm{Hz}$. Eyyûb, hem maddî hem de manevî olarak zarara uğramıştır. İhtimal olunur ki, düzenli olan işleri bozulmuş, çocukları ve hizmetçileri üzerindeki otoritesi zayıflamış ve sonunda başını alıp bir tarafa çekilmiştir. Vakti saati gelip çilesi tamamlanınca, Allah kendisine malını, mülkünü, çocuk ve hizmetçilerini iade etmiş ve düzenini tekrar kurmuştur. Nitekim tamamen elden çıkmış ve telef olmuş şeylerin Allah

65 Mu'tezîle burada hastalığın Şeytan'a nispet edilmesi açısından kıssanın bu yönüyle anlaşılmasını ta’n eder. Zira Ali Cübbâi (ö.303/915), hastalığın Şeytanın fiili olduğunu söylemenin cehalet olduğunu söyler. Hastalığın bedenlerden kaynaklı bir durum olduğunu belirtir. Bunun Allah'ın musallat kılması olarak Şeytan'a izafe edilmesine karşı çıkar. Bu görüşlerin hepsi için bkz. Râzî, Tefsiri, XXII, 208-209.

66 Ebû Mansûr el-Maturîdî, Te'vilâtu'l-Kur'ân, nşr. Ahmet Vanlıoğlu, Mizan Yay, İstanbul 2007, IX, 311-312.

67 Sâd 38/42.

68 Enbiyâ 21/84

69 Sâd 38/43. 
tarafindan kendine iade edilmesi kadar tabii bir şey olamaz. Allah (c.c.) mahvolmuş ve ölmüş olan bu şeyleri diriltmiştir ya da normal yollarla $\mathrm{Hz}$. Eyyûb’a geri kazandırmıştır. Başka bir görüşe göre de bunların ecir ve sevabinı ona kiyamette verecektir ${ }^{70}$. Ayrıca Hins-i Eyyûb hususunda onun yemin keffâretinde hanımına karşı şefkat göstermesinin istenmesi, bunun da insanlığa bir örnek olması Kur'ân'ın kıssa hikmetlerinden biridir $^{71}$.

Sonuç olarak, Enbiyâ sûresi 84. ayette geçen "kulluk edenlere hattra olmak üzere” beyanda olduğu üzere Hz. Eyyûb’ün sinanması insanlık için önemli bir örnek teşkil eder. Bu örneklikle onun yükseldiği sabır ufku, edep ve hayırla sonlanan akıbetlerin zirvesidir. Ayrıca burada kulluk edenlerin her an imtihan olduklarına dair ince bir telmih vardir ${ }^{72}$. Kullukta muvaffakiyet ve ahirette mükâfat dünya meşakkatlerinde sabırlı olmayı gerektirir. Nitekim Hz. Eyyûb kıssası örneğinde olduğu gibi güzel bir sabırla Allah'a sığınma, kişiyi akıbet olarak esenlik ve felaha götürecektir.

\section{EYYÛB KISSASININ DÜŞÜNDÜRDÜKLERİ}

Kur'ân'da kıssaların varlık sebepleri ${ }^{73}$ tefsir usûl kitaplarında zikredilmektedir. Bunlardan biri Hz. Peygamber ve imanları nedeniyle yurtlarından çıkartılan, her türlü sıkıntı ve baskıya maruz kalan Mü'minleri teselli etmektir ${ }^{74}$. Bu kıssada Allah, Hz. Peygamber üzerinden tüm insanllğga Eyyûb’ün (a.s.) sabrını somut örneklerle ögüt vererek

70 İbn Kesir, Tefsiri, V, 362-363; Alûsî, Rubu'l-Meânî, XVII, 81.

71 Ayette şöyle buyrulur: "Ey Eyyûb! Şimdi sen eline bir demet ekin sapr al, onunla (eşine) vur, böylece yeminini bozmamıs olursun. Gerçek şu ki, biz. Eyyûb'u sabırl bulduk. O, ne güzel kuldur. O, daima Allab'a yönelirdi” (Sâd 38/44).

72 Seyyid Kutub, Fî Zilâli'l-Kur'ân, çev. M. Emin Saraç, B. Karlığa, İ.H. Şengüler, Beyan Yay., İatanbul ts., X, 162-163.

73 Kıssaların gayeleri başlıklar halinde şöyle sıralanabilir: 1. Hz. Muhammed'in nübüvvetini ispat etmek. 2. Hz. Peygamber'i ve Müminleri teselli etmek. 3. Muhatapları düşündürmek ve ibret almalarını sağlamak. 4. İslâm'ın evrenselliğini ortaya koymak 5. Bütün peygamberlerin ortak yönlerinin İslâm'a çağıran tevhid eri olmasi. (Bu son madde bizim kendi ilavemizdir). Diğerleri için bkz. Muhsin Demirci, Tefsir Usûlü, İFAV Yay. İstanbul 2015, s. 211-213.

74 M. Sait Şimşek, Kur'an Kıssalarına Giriş, Yöneliş Yay., İstanbul 1993, s. 73-78. 
onların kıssadan hisseler alınmasına olanak tanımıștır. Tüm kıssaların özellikle Eyyûb kıssasının Hz. Peygamber'in hayatıyla çok yakın alakası vardır. Dolayısıyla Hızır-Musa kıssası dâhil olmak üzere hepsi $\mathrm{Hz}$. Peygamberin hayatiyla müşterektir.

Ayetlerde Eyyûb, malı, mülkü, ailesi ve çocukları, hatta sağlığ1 elinden alınmasına rağmen imtihanlara sabreden, Rabbine bağlllığını asla kaybetmeyen örnek bir insan olarak anlatılır. İlk ayetler nazil olduğunda Hatice validemiz ve Ebû Tâlib vefat etmişti. Bunlar, Resûlullah'ın en büyük destekçileri idiler. Hz. Hatice en zor zamanlarında dert ortağ1 olduğu gibi aynı zamanda onun çocuklarının annesi idi. Hanımını ve amcasinı kaybetmek elbette Hz. Peygamber'e ağır gelmişti. Bu esnada Eyyûb (a.s.) ile ilgili ayetler inerek, ona Eyyûb gibi sabretmesi anlatılmış ve hüznü için teselli edilmişti ${ }^{75}$. Nitekim ilk ayetlerin indiği zaman ve Eyyûb kıssası sabır noktasında benzeşmektedir.

Eyyûb kıssası, kıssadan hisse olarak bize üç şeyi öğretmektedir. Bunlar başlık olarak: Allah'a sabırla sığınmak, tedavi olmak ve eşlere iyi davranmak şeklinde sıralanabilir. Şimdi bunları ayet ve rivayetler ışı̆̆ında açıklamaya çalışalım.

\section{A- Allah'a Sığınmak ve Sabır}

Eyyûb kıssasında, bela ve musibetlere varıncaya kadar, Allah'in güzel esmâsına sarılarak tazarru ve Allah'a huşu ile sığınmanın güzel örneğini vardır. Bu durumda Eyyûb Peygamber üzerinden Allah'a iman ve kullukta sabır örneğini görmekteyiz.

İbn Kesir, Sâd sûresinde belirtilen Hz. Eyyûb’ün düştüğü sıkıntıyı şöyle anlatır: Eyyûb (a.s.), hastalık ve imtihan öncesinde bolca dünya malına ve çocuklara sahipti. Allah Teâla, Eyyûb Peygamberi mal ve çocuklarına gelen zararın yanında onu bedeniyle de imtihan etmiş vücudunda kalbi dışında iğne ucu kadar yara olmayan yeri kalmamıştı. Hastalığı için yardım isteyeceği hiçbir kimsesi yoktu. Ancak imanı sebebiyle hanımı onu seviyordu. Ücretle hizmet ederek Hz. Eyyûb’ü doyuruyordu. Böylece rivâyetlerde en uzun vakti belirtildiği üzere $\mathrm{Hz}$. Eyyûb'e on sekiz sene hizmet etmiştir. Bir mezbeleliğe atılmasına rağmen

75 Süleyman Ateş, Yüce Kur'ân'mn Cağdaş Tefsiri, Yeni Ufuklar Neşriyât, İstanbul 1990, $\mathrm{V}, 518$. 
hanımı akşam sabah hizmet ederek yanından hiç ayrılmamıştır. Hz. Eyyûb'ün hastalık hali şiddetlenince, nihayet onun hakkında mukadder süre tamamlanınca Allah'a tazarru da bulunmuş: "Bu dert beni sarverdi. Sen merhametlilerin en merbametlisisin" ş şeklinde dua etmiştir. "Rabbim doğrusu seytan bana yorgunluk ve aqap verd?" yorgunluğun, bedenindeki hastalık; azabın da malı ve çocuklarına gelen zeval olduğu tefsirlerde belirtilmektedir ${ }^{78}$.

Sabrı ve her halde șükrederek Allah'a (c.c.) sı̆̆ınması hadislerde şöyle anlatılır: Eyyûb’ün birisi buğday, diğeri arpa olan iki ambarı vardı. Allah Teâla iki bulut gönderdi. Bunlardan birisi buğday deposunun üzerine gelince depoya dolup taşıncaya kadar altın boşalttı. Diğeri de taşıncaya kadar arpa ambarına altın boşalttı. Ebû Hureyre'nin rivayetine göre de Allah resulü şöyle buyurmuştur: Eyyûb (a.s.) çıplak olarak yıkandığı zaman üzerine altın çekirgeler boşalmaya başladı. $\mathrm{O}$, bunlardan elbisesi içine doldurmaya başladı ve Rabbi kendisine: 'Ey Eyyûb şu gördüklerinden seni müstağni kılmadım mı?’ Diye nida eyledi. $O$ da: 'Evet müstağni kıldın Rabbim. Fakat senin bereketinden asla müstağni değilim', şeklinde Allah'a cevap verdi ${ }^{79}$.

Sonuç olarak "Katımızdan bir rabmet ve akell sahipleri için bir de öğ̈̈t olmak üzere ona, ailesini ve onlarla birlikte olanlarn bir mislisini lütfettik"” (Sâd 38/43) ayetinde ve hadislerde belirtilen lütuf, sabrı karşıllğında kat kat Hz. Eyyûb ve ehline verilen mükâfattır. Zira bizzat onları diriltmiş ve onların bir misliyle artırmıştır. Tefsir olarak burada Allah (c.c.) şöyle buyurur: Sabrı, sebâtı ve tevazu ile boyun eğmesi karşılı̆̆ında ona katımızdan bir rahmet; sabrın akıbetinin de ferahlık ve darlıktan çıkış

\footnotetext{
76 Enbiyâ 21/83.

77 Sâd 38/41.

78 İbn Kesîr, Tefsiri, VII, 74.

79 Birinci rivâyetin kıssayla bütünlüğü için bkz. Ahmed b. Abdullah el-Isbehânî Ebû Nuaym, Hilyetu'l-Evliyâ ve Tabakâtü'l-Esfìyâ, Matbaatü's-Sa'ade, Kahire 1974, III, 375. İkinci hadisi de Abdurrezzâk tarikiyle sadece Buharî tahriç etmiştir. Bkz. İbn Kesîr, Tefsiri, VII, 75; ikinci rivâyetin diğer varyantları için bkz. İbn Kesîr, Bidâye, I, 511-513.
} 
olduğunu bilsinler; yine akıl sahiplerine öğüt olsun diye, ailesini ve yanında bulunanların mislini ona lütfettik ${ }^{80}$.

Böylece Yunûs peygamberde olduğu gibi, Eyyûb (a.s.) kıssasında, peygamberlerin bile darlık sinavlarından geçirildikleri; onların da beşer oldukları; başkalarının hastalıklarını iyileştirmeleri söz konusu olmadığı gibi, kendi sağllkları için Allah'a dua etmekle mükellef oldukları anlatılmıștır. Buradan hareketle Kur'ân'da vurgulanmak istenen ilk hakikat, bütün Peygamberlerin tevhide çağırmakla sorumlu olmalarıdır. İmandan sonra imtihan süresi uzasa da sabırla niyazda bulunarak asla ümidin kaybedilmemesi ve her konuda yalnız Allah'a sığınılması, peygamberler üzerinden insanlı̆̆a öğretilmiştir ${ }^{81}$. İnsanoğlu hangi mertebeye ulaşırsa ulaşsın hastalık sıkıntılardan hâli olamayacaktır. Dolayısıyla inananların en bariz vasfi sabır olduğundan zorluklarla karşılaştığında sığınacağı yegâne varlık Mevlâ’dır.

\section{B- Tedavi Olmak}

Kıssanın Hz. Eyyûb üzerinden bizlere öğrettiği şey, Allah'ın nebisine bildirdiği üzere tedavinin vacip olmasıdır. Zira ayette; "Rabbim bassıma bir dert geldi (bu dert beni sarverdi). Sen merhamet edenlerin en yücesisin' niyazım etmişti. Biz de onun duasm kabul etmis, onu yakalandiğ dertten (hastalıktan) kurtarmışık..."82, beyaniyla Cenâb-1 Hâk, Hz. Eyyûb’ün duasını kabul etmiş ve göstermiştir. Zira "Ayağım yere vur. Isste ynkanılacak ve icilecek soğuk su bu"83 ayetteki emirle, merhametlilerin en merhametlisi, fiilî dua olan tedavi yöntemini göstererek duasına icabet etmiştir. Hz. Eyyûb, yattığı yerden doğrularak ayağıyla yere vurunca Allah (c.c.) oradan bir kaynak fişkırttı. Bununla bedenindeki hastalıkları tamamen iyileşti. Sonra başka bir yere ayağını tekrar vurmasını emretti. Oradan da başka bir kaynak fışkırttı. Buradan da içmesini emretti. Böylece içindeki zorluklara teslim olma kaygısı ve gönlündeki kasvet de giderilmiş; zâhir ve bâtın olarak tam bir afiyete kavuşmuştu ${ }^{84}$. Kanımızca ayette zikredilen

\footnotetext{
80 İbn Kesîr, Tefsiri, VII, 75.

81 Mevdûdî, Tefhimu'l-Kur'an, III, 299; yine krş. Mevdûdî, a.g.e., V, 76.

82 Enbiyâ 21/83-84)

83 Sâd 38/42.

84 İbn Kesîr, Tefsiri, VII, 74-75.
} 
bu hususla; Hz. Eyyûb'ün geçirdiği hummalı rahatsızlık sonucu meydana gelen vücut 1sısının soğuk suyla düşürülmesi ve normal bir vücut isısına sahip olması kastedilmektedir.

Enes b. Malik'ten rivâyet edildiğine göre Allah Resûlü şöyle buyurdu: A Eyyûb (a.s.), on sekiz yll musibet içinde kaldı. Yakın ve uzağındakiler onu reddetti. Ancak onun en yakın kardeşlerinden iki kişi vardı ki, onlar sabah akşam ona gelir giderlerdi. Onlardan birisi diğerine, 'Allah'a yemin olsun ki Eyyûb âlemlerden hiç kimsenin işlemediği bir günahı işlemiştir'. Diğeri de: 'bu günah nedir deyince, on sekiz seneden beri Allah merhamet edip bulunduğu durumdan onu kurtarmıştır' (daha ne olsun dedi). Hz Eyyûb de: 'Ancak Allah biliyor ki ben çekişmeleri sırasında iki kişiye uğradım ve döndügüumde Allah'ı zikrederken haksızlığa düşebilecekleri korkusuyla onların yerine kefaret verirdim' derdi. Râvi devamında şöyle der: Hz. Eyyûb def-i hâcet işini bitirdiğinde karısı onun elinden tutar, eski yerine getirmeye yardım ederdi. Bir gün def-i hacetten sonra eşini çağırmakta gecikti. O esnada Allah, Hz. Eyyûb'e: 'Ayağını yere vur işte yıkanılacak, işte içilecek soğuk su bu' dedi. Hanımının da yanına gelmekte gecikmesini istedi. Hanımı onu beklemeye başladı. Hastalıkların giderildiği bir kişinin karşısında durduğunu görünce hanımı ona: 'Allah seni mübarek kılsın, şu musibete duçar kalmış Allah'ın peygamberini gördün mü? Sihhatli haline senin kadar benzeyen başka birisini görmedim’ dedi. Hz. Eyyûb de: 'Işste gördüğün benim!' diyerek bizzat kendisi olduğunu beyan etti ${ }^{85}$.

Hz. Eyyûb’ü rahatsızlığının anlatımında, onun şiddetli bir hastalığa yakalandiktan sonra cesedinin koktuğu, bedeninden kurtların çıktığ1 ve nihayet insanların ondan nefret ettiği ve şehirden uzaklaştırıldığ kabilinden anlatılan rivâyetler, isrâiliyyât türü uydurma şeylerdir. Bunların

85 İbn Ebî Hâtim, Tefsiru'l-Kur'âni'l-Azîm, VIII, 2459-2460; Ebû Nuaym, Hilye, III, 374-375; İbn Kesîr, Tefsiri, VII, 75. Bu durumu İbn Abbas'tan farklı ilaveyle anlatmıştır. Allah duçar kıldığı belânın sonunda Eyyûb'e cennet giysilerinden bir hulle giydirdi. O da uzaklaşıp bir köşeye oturdu. Karısı geldiğinde onu tanımadı ve: 'Ey Allahın kulu şuracıkta belaya duçar kalmış kişi nereye gitti? Herhalde köpekler kurtlar onu götürmüş olsalar gerek' dedi. Eyyûb de: 'Yazık sana! Ben, Eyyûb’üm ve Allah, sağlığımı bana geri verdi’ dedi. Bkz. İbn Kesîr, Tefsiri, V, 362. 
gerçekle hiçbir ilgisi yoktur ${ }^{86}$. Çünkü bunlar ilgili ayetlerin manasına ve Kur'ân'ın kıssa anlatım üslûbuna terstir. Zira ona rahatsızlık geldiğinde Rabbine dua ettiği, Rabbinin de onu iyileştirdiği Kur'ân'da anlatılmaktadır. Peygamberler de insandır ve hasta olurlar. Ancak hastalıkları insanları kendisinden uzaklaştıracak ve nefrete dönüştürecek derecede olmaz. Çünkü Peygamberler, evsaflarında beşerî eksikliklerden beri ve insan-1 kemâl ile muttasıflardır ${ }^{87}$.

Ayetlerden $^{88}$ hareketle, sağllk konusunda Allah'a yalvarmanın yöntemini ve tıp ilminin kaynağının da ilahî rahmetin bir tecellisi olduğunu bilmek gerekir. Zira Allahın merhameti olmazsa şifa da olmayacaktı. Tibbin arzuladığ1 son nokta şifa da Allah'in merhameti olarak gerçekleşmektedir. Bu meyanda hastalık ve mikroplar tabiat (sünnetullah); şifa da ilahî merhamet gereğidir ${ }^{89}$. Kissada Hz. Eyyûb’ün yalvarış şekli, mikroba ilaç bulmak ve bu alandaki öğretiyi edinme çabasının kulluk ödevi olduğunu göstermektedir. Bu aşamaların da fiilî dua bağlamında Cenab-1 Hakk'ın rahmetinde saklı olduğunu bilinmelidir. نت أرحم الراحمين Nitekim ayetin sonunda, “...sen merhametlilerin en yücesisin ¡..." ${ }^{\circ 0}$, şeklindeki beyanla bu husus teyit edilmektedir.

\section{C- Eşlere İyi Davranmak}

Hz. Eyyûb kıssasının vermiş olduğu mesajlardan birisi de eşe karşı iyi davranmanın önemidir. Eyyûb (a.s.) sıhhat ve zenginlik halinde hanımına iyi davranıyordu. Essi de zor zamanlarda ona iyilikte bulunuyordu. Ancak hatasından dolayı eşine yüz değnek vuracağına dair

86 Bulut, a.g.e., s. 21. Burada Allah'ın seçkin kulu ve nebisi olan bu yakıştırmalar yapmak, bunları din diye anlatmak, kitaplara aktarmak günahtır. Bunlarla dine ısındırma olmaz. Temizliğe ve sağlığa önem veren kimse bunları dinleyince nefret edebilir. Hatta dinden, peygamberlerden soğuyabilir. Dolayısıyla bu haberlerin hepsi maksatlı olup tahrif özelliği taşımaktadır. Yüce İslâm’ın en bariz özelliği temizlik ve sthhati korumaktır. Burada verilmek istenen ana mesaj, hastalanınca tedavi olmak ve sabırla sonuca ulaşmada gösterilmesi gereken gayrettir. Aydemir, a.g.e., s. 104.

87 Râzî, Mefâtihu'l-Gayb, XXII, 208.

88 Bkz. Enbiyâ 21/ 83, Sâd 38/42.

89 Bayraktar Bayraklı, Yeni Bir Anlayışın Işı̆̆ında Kur'ân Tefsîri, Bayraklı Yay., İstanbul 2003, Tefsiri, XII, s. 500.

90 Enbiyâ 21/83. 
yemin etmiş, Cenâb-1 Hak da Hz. Eyyûb'e vefa olarak yeminin kefaretinin hafifletilmesini emretmiştir. Böylece Allah (c.c.), eşlere iyi davranmanın, vefaya karşı ihsanda bulunmanın örneğini Hz. Eyyûb üzerinden tüm insanlığa öğretmiştir.

Rivâyetlere göre Hz. Eyyûb, yatağında hasta iken hanımına yüz sopa vuracağına dair yemin etmişti. Sopayla dövmeyi gerektiren sebep rivâyetlerde farklı şekillerde anlatılmaktadır ${ }^{91}$. Bu durumun sebepleri konusunda ihtilaflar olsa da Maturîdî, Hz. Eyyûb'ün hangi sebeplerden dolayı hanını dövmeye yemin ettiğini hakkında malumatının olmadığını ve böyle bir bilginin gereksiz olduğunu söyler. Ayetteki haberle bilinen ise Hz. Eyyûb için yemin edilen bir durumun ortaya çıkması, Allah'ın bu dövmeye dair yemini yerine getirmesini kendisini emretmesidir. Muhtemelen Eyyûb’ün burada kızması ve yemin etmesi, kendi nefsi için değil, bilakis Allah içindir. Çünkü Peygamberlerden kendi nefislerinden dolayı gazap sadır olmaz. Ancak kızılması gereken kimse (ler) için onlardan böyle durum sadır olabilir ${ }^{92}$.

Bu konuda Allah Eyyûb peygambere şöyle buyurur: "Eline bir demet sap al da onunla vur ve yeminini bozma. Biz onu gercekten saburl bulmustuk. $\mathrm{Ne}$ iyi bir kuldu. Mubakkak ki o, Allah'a yönelirdi"'93. Allah bu ayetle $\mathrm{Hz}$. Eyyûb'e, 'Eline bir demet sap al da onunla vur ve yeminini bozma' diyerek haber vermesi şöyle izah edilir: Hz. Eyyûb, bir işten dolayı hanımına öfkelenmiş

91 1-İbn Abbas'tan rivâyetle, Şeytan iyi bir surette Eyyûb’ün karısıyla karşılaştı. Ona Eyyûb’ü tedavi edeceğini ve bir karşıllı beklemediğini söyledi. Karısı da bunu Eyyûb'e anlatınca, o da Şeytan olduğunu anladı ve bu Şeytana yazık osun diyerek karısına vurmak konusunda yemin etti. 2-Said İbn Müseyyeb’ten rivayetle, Ona daha önce getirdiği ekmeklerden daha fazla ekmek getirince ona vuracağına dair yemin etti. 3-Yahya b. Selâm ve diğerlerinden rivâyetle Şeytan karısına iğvâ verdi. Şöyle ki, kendine yakınlaşması konusunda bir kuzuyu kurban kesmesi ve böylece iyileşeceğini Eyyûb’e zikretti. Bunun üzerine Eyyûb de ona yüz sopa vuracağına dair yemin etti. 4-Denildiğine göre Eyyûb’ün karısı ona yiyecek götürmek için bir şey bulamayınca, saç örgülerinden sattığında, ayağa kalkınca ona vuracağına dair yemin etti. Sonra Allah ona, hastalı̆̆ına şifa bulunca bir demet sap almasını, bunları yüze tamamlayıp ona vurmasinı emretti. Bkz. Muhammed b. Ahmed el-Kurtûbî, el-Cami lî Abkâmi'l-Kur'ân, thk. Abdu'l-Muhsin et-Türkî, Müessesetü'r-Risâle, Beyrût 2006, XVIII, 217-218.

92 Maturûdî, Te'vilât, XII, 263-264.

93 Sâd 38/44. 
ve kızmıştı. Rivâyete göre eşi onu doyurmak için saçının bir örgüsünü satmış ve Eyyûb'e yiyecek yedirmişti. Bundan dolayı Eyyûb de hanımını kınamış, Allah kendisine şifa verirse hanımına yüz değnek vuracağına yemin etmişti. Hz. Eyyûb şifa bulduktan sonra en güzel şekilde kendisine husn-i muamelede bulunan eşinin yaptıklarının karşıllğı yüz değnek olmaması abes bir durumdu. Zira Allah Teâla, Hz. Eyyûb'e vahyederek eline bir demet sap almasını, bu demet içinde yüz sap bulunmasını ve bu demetle hanımına bir kerede vurmasını emretmiştir ${ }^{94}$. Böylece Hz. Eyyûb yemin akdine uymuş olacak ve bu şekilde yemininden dönen (hânis) olmayacaktı ${ }^{95}$. İşte bu husus, Allah'tan korkan ve O'na dönen için bir ferahlık ve çıkış yolu olmuştur. Böylece Allah Teâla: "Biz, onu gerçekten sabirl bulduk, ne iyi bir kuldu. Mubakkak ki o Allab'a yönelirdi” buyurarak Hz. Eyyûb’ü iyi bir kul olması ve Allah'a her durumda dönüp yönelmesi ile övmüştür. Bunu teyit mahiyetinde başka bir ayette; "Kim Allah'tan korkarsa, Allah ona bir çıııs yolu ibsan eder ve ona beklemediği yerden mak verir" (Talak 65/2, 3) buyrulur ${ }^{96}$. Fakihlerden çoğu, yemin ve benzeri meselelerde bu ayeti kerimeyi delil getirerek, yemin keffâreti hususunda hüküm getirmişlerdir. Bazı fikıhçılar da bu işi daha da genişleterek "yeminlerden kurtulmak için hileler" bölümünü fikıh kitaplarında işlemişlerdir. Konunun başına da bu ayet-i kerimeyi yerleştirmişlerdir ${ }^{97}$.

Kurtubî, bu ayetin te'dîb için erkeğin kadını dövmesi için cevaz içerdiğini söyler. Zira Eyyûb, hanımı bir hata ettiği zaman, ona yüz sopa atacağına dair yemin etmişti. Allah'ta ona ekin (hurma salkımı) sapıyla demet yaparak vurmasinı emretti. Ancak bu, had cezası için caiz bir durum değildir. Allah, edep haddinin dışında eşin dövülmemesini beyan

94 Burada “ضغ/ziğg” konusunda ihtilaf edilmiştir. Bu yaş ot, dal vb. anlamlara gelir. Yalnız bu durum Eyyûb’e (a.s.) özgü bir durumdur. Bkz. Maturîdi, Te’vilât, XII, 263.

95 İslam fikhına göre, yapilan her hangi bir yemine riâyet etmeyip aksine hareket etmektir. Yeminine bağlı kalmayıp bozan kimseye de "hânis" denir. Mehmet

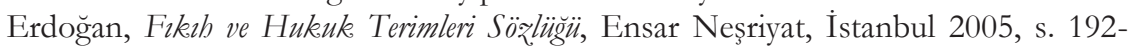
193.

96 İbn Kesîr, Tefsiri, VII, 76.

97 Bu görüşler için bkz. İbn Kesîr, Bidâye, I, 514, Bu durum eşe merhameti ve yemine saygınlığ1 gösterirken Süleyman Ateş, bazı fakihlerin ayeti kişisel çıkarları için dinin farzlarından kaçmaya vesile kıldıklarını söyler. Devamı için bkz. Ateş, Tefsiri, VII, 477-478. 
eder. $\mathrm{Bu}$ da ferdin edep hakkı harici karısını dövmemesi gerektiğini ortaya koymaktadır. Bu husus Nisâ sûresinde beyan edilmiştir ${ }^{98}$. Ayrıca had cezası veya ta'zir gibi ukûbat meseleler için hadislerde şefkat ve merhamete dair hükümler vardır ${ }^{99}$. Ancak hıns-1 Eyyûb hususundaki keffârete dair ihtilaflar ${ }^{100}$ konumuzla doğrudan alakalı olmadığı için, bu hususları ana metne dâhil etmek istemiyoruz.

Sonuç olarak burada asıl mesele, tazim bağlamında yeminin yerine getirilmesi gerekse de vefa için ayetteki rahmet örneğinde olduğu üzere eşlere karşı merhametli davranılmasıdır. İmam Mâturidî̀ye göre de elindekini değil, nefsini dövmek caizdir. Zira o, şeriatta azimeti tercih ederek dövmeyi terk etmenin; yemini bozduğu için de keffâreti yerine getirmenin gerektiğini söyler ${ }^{101}$. Onun insanı merkeze alan anlayışı maslahat açısından mühimdir. Dolayısıyla naslardan hareketle, eşlere vefa ve merhamet göstermek; naif olduklarından ötürü onlara karşı şiddete gitmemek Allah’ın, Hz. Eyyûb üzerinden insanlığa öğrettiği önemli bir husustur. Zira İslâm'ın insanlı için tüm inananlara emrettiği temel umdelerden biri merhametli olmaktır.

98 Nisâ 4/34. İslam fakihleri, bu ayetin (dövme) hükmünün yalnız Hz. Eyyûb’a özgü bir durum mu yoksa genel mi? oluşu konusunda ihtilaf etmişlerdir. Mehdevî̀nin rivâyetine göre Atâ b. Ebî Rebâh, ayetin hükmü bâkidir ve yüz kazîb (yaş ot) ile bir defa vuran kimse sözünü yerine getirir. İmam Şafî̀ (ö. 204/819) buna katılmaz. Kurtubî, el-Cami' XVIII, 218-219; Ateş, Tefsiri, VII, 47.

99 Ebû Dâvûd'un (ö. 275/888) naklettiğine göre, bir cariyeyi gebe birakmış olan yatalak birisi hakkında, Hz. Peygamber'in, içinde yüz hurma salkımı ile ona bir kere vurulmasını emrettiği rivâyet edilir. Bkz. Süleyman b. Eş’âs Ebû Dâvûd, es-Sünen, Çağrı Yay, İstanbul 1992, "Hudûd”, 33.

100 Hadislerde de had cezası olsa bile İmam Şafî̀, falana yüz değnek vuracağım deyip, 'yüz şiddetli değnek vuracağım' demeyip içinden şiddeti geçirmemişse, ayette anlatıldığı üzere (yüz sap ile) bir defa vurmakla sözünü yerine getirmiș olacağını söyler. Re'y taraftarları da bu görüştedirler. Ancak bu hususta farklı düşünen İmâm Mâlik'e (ö. 179/795) göre acıtmayan dövme vurmak değildir. Bu farklı görüşler için bkz. Kurtubî, el-Cami', XVIII, 220.

101 Maturûdî, Te'vilât, XII, 264. 


\section{SONUÇ}

Kur'ân'ın kendine has üslubu, kıssalarına da yansır. O, kıssa anlatımında objektif bir anlatım ortaya koyar. Kur'ân, kıssa üslubu bakımından teferruata düşmeden konuyu net bir dille anlatır, muhatabın mesajı doğrudan almasını sağlar.

Hz. Eyyûb'ün hayatının, uzun ve yaşam hikâyesinin imtihanlarla dolu olduğu -pek çoğu doğru olmayan isrâiliyyât türü haberler olsa bilehakkındaki mezkûr rivâyetlerden anlaşlabilir. Onun büyük imtihan karşısında sabır dolu hayatını Kur'ân-1 Kerim çok veciz bir şekilde özetlemiştir. Ayetlerin ikisinde ondan nebi olarak bahsedilmiş, diğer altı ayette hayatı kıssa edilmiştir.

Kur'ân'da Eyyûb kısasının sunduğu ana tema; mal, evlat ve sthhatine bir halel geldiğinde, durumunu doğrudan Allah'a (c.c.) beyan etmesi ve sıkıntılarda yaratanın rahmetine sı̆̆ınmasıdır. Kitâb-1 Mukaddes'e ve tefsir literatürüne bakıldığında, Hz. Eyyûb ile ilgili bir yığın bilgiye rastlanır. Özellikle hastalık sürecinde dert ile ilgili isyan etmekten serzenişte bulunmaya kadar, yara bere içinde kalmaktan kurtları vücuduna tekrar iade etmeye kadar, itikadî bağlamda bir peygambere isnat edilmeyecek bir yığın haberin İslâm kültürüne dâhil edildiği görülür. Böyle sabrını anlatmak için yaralarına kurt düşen ve kurdu tekrar alıp yarasına koymayı kaderi gören peygamber tasviri doğru olmaz. Bu tür rivâyetler ile İslam'a 1sındırmak ve temel ilkelerini kavratmak isteyenler dinden soğutmaktan öteye de gidemez. Ayetten anlaşlan, hastalanıldığında sünnetullah gereği şifa için tedavi hususunda gereken muamelelerle tedbirin elden birakılmamasıdır. Yoksa Kitâb-1 Mukaddes'te ve isrâiliyyât türü haberlerde belirtildiği üzere, günahından ötürü belaya maruz kalan ve haline isyan eden, İblis'in kendisine galip geldiği, hastalıktan yara bere olmuş ve hezeyanlar savuran şeklindeki tasvirlerle Hz. Eyyûb'ü anlamak büyük hata olur. Nitekim peygamberler, bu tür vasıflardan münezzehtirler. Oysaki her daim onlar, en zor bela ve musibet anlarında dahi, sabır ve Allah'ın rahmetine sığınma konusunda örnek olmuşlardır.

$\mathrm{Bu}$ zorluklar1 atlatırken verilmek istenen ana tema, sadece Mevla'yı zikretmek ve sabırla ona kulluğa yönelmektir. Zira kıssaların bir amacı da Hz. Peygamber'i teselli etmektir. Bu kıssada da zorluklara karşı 
sabır gerektiği ona öğretilmiş; Hz. Eyyûb’ün yaşadığ1 sıkıntıların gösterilmesiyle de hayat ve dava uğruna sabrın güzelliği ve selameti için Hz. Peygamber ve ümmeti teselli edilmiştir.

Kur'ân kıssaları hidayete vesile olması amaciyla, hak ile kıssa edilen her bir peygamberin tevhid eri olduğuna vurgu yapar. Hz. Eyyûb kısasında da veciz olarak birkaç husustan bahsedilmekle beraber, onun üzerinden Allah'a sabırla sığınmak, tedavi olmak ve eşlere güzel muamelede bulunma şeklinde üç mesaj verilmektedir. Kıssacıların yaptığı gibi Kitab-1 Mukaddes'in ve ondan sadır olan şifahî kültürün ürünleri kabul edilirse, Kur'ân'1 Kerim'in anlattığ1 Hz. Eyyûb'ün gerçek şahsiyeti silinecektir. Oysaki Kur'ân, onu, her türlü musibet karşısında Allah'a yönelen güzel bir kul olarak vasıflandırmaktadır. 


\section{KAYNAKÇA}

Ahmed b. Hanbel, el-Müsned, Çağrı Yay., İstanbul 1992.

Albayrak, Nurettin, “Eyyub”, DİA., İstanbul 1995.

Alûsî, Şihâbudin Seyyid Mahmûd, Rubu'l-Meânî, İhyâu Türâsi'l-Arabî, Beyrut trs.

Ateş, Süleyman, Yüce Kur'an'ın Cağdaş Tefsiri, Yeni Ufuklar Neşriyat, İstanbul 1998.

Aydemir, Abdullah, İslâmî Kaynaklara Göre Peygamberler, TDV Yay., Ankara 1992.

--------, Tefsirde İsrailiyyat, Beyan Yay., İstanbul 1992.

Bayraklı, Bayraktar, Yeni Bir Anlayışın Isıı̆̆ında Kur'ân Tefsîri, Bayraklı Yay., İstanbul 2003.

Begavî, Ebû Muhammed b. Hüseyin b. Mes'ûd, Meâlimu't-Ten₹îll, Dâru'lMarife, Beyrût 1987.

el-Behît, Ebû Bekir Muhammed Fevzî, Hasâisu Uslûbi'l-Kur'ânî, Melik Suûd Üniversitesi, Mekke 1436/2014.

Bulut, Mehmet, Ebli Sünnet ve Şia'da İsmet İnancı, Risale Yay., İstanbul 1991.

Buharî, Muhammed İsmail, Câmiu's-Sahîh, Çağrı Yay., İstanbul 1992.

el-Bûsîrî, Şehâbeddin Ahmed b. Ebî Bekr el-Kinânî, Misbâbu'z-Zücâce fî̀ Zevâid-i İbn Mâce, Dârû'l-Cinân, Lübnan 1986.

Cerrahoğlu, İsmail, Tefsir Usûlü, Türkiye Diyanet Vakfı Yay., Ankara 1985.

Demirci, Muhsin, Tefsir Taribi, İFAV Yay., (4.Bask1), İstanbul 2008.

--------, Tefsir Usûlü, İFAV Yay., İstanbul 2015.

Ebû Dâvûd, Süleyman b. Eş’âs, es-Sünen, Çağrı Yay, İstanbul 1992.

Ebû Nuaym, Ahmed b. Abdullah el-Isbehânî, Hilyetu'l-Evliyâ ve Tabakâtü'l-Esfiyâ, Matbaatü's-Sa'ade, Kahire 1974.

Erdoğan, Mehmet, Fıkıh ve Hukuk Terimleri Sözlüğ̈̈, Ensar Neşriyat, İstanbul 2005. 
Harman, Ömer Faruk, "Eyyûb”, DİA, İstanbul 1995.

İbn Asâkir, Ali b. Hasan, Tebžibu Târibi Dimeşki'l-Kebîr, Dâru'l-Mesîre, Beyrut 1979.

İbn Aşûr, Muhammed Tahir, et-Tahrîr ve't-Tenvîr, Müessesetü't-Târîh, Beyrût 2000.

İbn Ebî Hâtim, Muhamed b. İdris, Tefsiru'l-Kur'âni'l-Ažîm, thk. Es'ad Muhammed Tayyib, Mektebetu Nizâr, Riyad 1997.

İbnü'l-Esir, Muhammed b. Abdilkerim, el-Kâmil fi't-Târih, Dâru Beyrût, Beyrût ts.

İbn Kesîr, Ebû'l-Fidâ İsmail, el-Bidâye ve'n-Nihâye, thk. Abu'l-Muhsin etTurkî, Dâru Hicr, Misır 1997.

-, Tefsiru'l-Kurâni'l-Azîm, Dâru Taybe, Riyad 1997.

İbn Mâce, Ebû Abdillah b. Muhammed, es-Sünen, Çağrn Yay., İstanbul 1992.

Kitab-1 Mukaddes, Eski ve Yeni Ahit, Kitab1 Mukaddes Şirketi, İstanbul 1958.

Komisyon, İslâm Taribi, Osmanlı Yayınevi, İstanbul 1985.

Köksal, Asım Peygamberler Taribi, TDV Yay., Ankara 1990.

Kurtûbî, el-Cami' lî Abkâmi'l-Kur'ân, thk. Abdu'l-Muhsin et-Türkî, Müessesetü'r-Risâle, Beyrût 2006.

Kutub, Seyyid, Fî Zilâli'l-Kur'ân, çev. M. Emin Saraç, B. Karlı̆ga, İ.H. Şengüler, Beyan Yay., İstanbul ts.

Maturîdî, Ebû Mansûr, Te'vilâtu'l-Kur'ân, nşr. Ahmet Vanlıoğlu, Mizan Yay, İstanbul 2007.

Mehmed Vehbî Efendi, Hülâsatü'l-Beyân, Ahmet Sait Matbaası, İstanbul 1968.

Merağî, Tefsirü'l-Merâ̆ğ̀̆, Ahmed Mustafa, Misır 1974.

Mevdudî, Ebu'l A'la. Tefhimu'l-Kur'an, İnsan Yay. İstanbul 1986.

Neccâr, Abdu'l-Vehhâb, Kısasu'l-Enbiyâ, Mektebe-i Dâri't-Türâs, Kahire trs. 
Özbek, Durmuş, Saduddin Teftazanî ve Nübüivet Görüşü, Sebat Ofset, Konya 2002.

Öztürk, Mustafa, Kıssalarn Dili, Ankara Okulu Yay., Ankara 2010.

Râzî, Fahreddin, Mefâtibu'l-Gayb, Dâru'l-Fikr, Beyrût 1981.

--------, '̇́smetü'l-Enbiyâ, Mektebetü’s-Sekâfetü'd-Diniyye, Kahire 1986.

Reşid Rıza, Muhammed, Tefsiru'l-Menâr, Dâru'l-Marife, Beyrût ts.

Salebî, Ebû İshâk Ahmed, 'Ara 'isu'l-Mecâlis/Kısasu'l-Enbiyâ, Matbaatü'lBehiyye, Misir 1301/1883.

Şengül, İdris, “Kur'ân'ın Mesajını Ulaştırmada Kıssaların Önemi”, I. Kur'an Semposyumu, Ankara 1994, s. 134-135.

Şimşek, M. Sait, Kur'an Kıssalarna Giriş, Yöneliş Yay., İstanbul 1993.

Tabbâre, Afîf Abdulfettah, Ma'al-Enbiyâ fíl-Kur'âni'l-Kerîm, Mektebe-yi Mahmûdiye, İstanbul ts.

Taberî, İbn Cerîr, Tarih-i Taberî, thk. Muhammed Ebu’l Fadl İbrahim, Beyrut ts.

--------, Câmiu'l-Beyân an Te'vîli'l-Âyi'l-Kur'ân, thk., Abdu'l-Muhsin etTürkî, Dâru Hicr, Kahire 2001.

Teftazânî, Ömer b. Abdillah Sa'duddin, Şerbu'l-Makâsıd, İstanbul 1277/1860.

Yazıcıoğlu, Ahmed Bican, Envâru'l Âşıkîn, Sağlam Kitabevi, İstanbul 1974.

Yazır, Ahmed Hamdi Elmalılı, Hak Dini Kur'an Dili, Eser Dağıtım, ys. 1979.

Yüksel, Yakup, Allab’n Uyardı̆̆g Peygamberler, Rağbet Yay., İstanbul 2016.

Zemahşerî, Mamûd b. Ömer, el-Keşsâf, Dâru İhyâi't-Türasi'l-Arabiyye, Beyrut 1997.

Zürkanî, Muhammed Abdulazim, Menâbilï'l-İrfân fì Ulûmi'l-Kur'ân, Dâru İhyâi'l-Kütübi'l-Arabiyye, ys. 1943. 